\title{
Macro-Financial Parameters Influencing Bitcoin Prices: Evidence from Symmetric and Asymmetric ARDL Models
}

\author{
P. SRINIVASAN \\ Presidency University * \\ BIPASHA MAITY \\ Presidency University \\ K. KRISHNA KUMAR \\ Presidency University
}

\begin{abstract}
Bitcoins are evolving as a modern class of investment assets and it is crucial for investors to manage their investment risk. This paper examines the impact of macroeconomicfinancial indicators on Bitcoin price using symmetric and asymmetric version of autoregressive distributed lag (ARDL) models with structural breaks. The asymmetric long-run association ascertained between Bitcoin prices and the macroeconomic-financial indicators is evident. Our empirical results indicate that the Bitcoin cannot be used to hedge against the inflation, Federal funds rate, stock markets and commodity markets. We further find that Bitcoin can be regarded as a hedging device for the oil prices. Our findings have significant implications for market participants who consider including alternate investment assets in their portfolios.
\end{abstract}

Keywords: Bitcoin, hedging asset, macro-financial parameters, symmetric and asymmetric ARDL models

JEL Classifications: C10, G11

\section{Introduction}

As Cryptocurrencies are evolving as a modern class of investment assets, the impact of macrofinancial factors on Bitcoin price has received considerable attention among the academicians and practitioner similar to the conventional investment assets viz. stock, gold, equity etc. Bitcoin price is determined by the supply and demand forces and influenced by macro-financial

\footnotetext{
* School of Management, Presidency University, Itgalpur, Rajanakunte, Yelahanka, Bengaluru 560064, Karnataka, India. P. Srinivasan, corresponding author, srinivasaneco@gmail.com; Bipasha Maity, bipasha@presidencyuniversity.in; K. Krishna Kumar, nakumark@presidencyuniversity.in.

(C) 2022 P. Srinivasan, Bipasha Maity and K. Krishna Kumar. Licensed under the Creative Commons Attribution - Noncommercial 4.0 Licence (http: / / creativecommons.org/licenses/bync/ $4.0 /$. Available at http://rofea.org.
} 
development (Kristoufek 2013; Bouoiyour and Selmi 2015 and Balcilar, et al. 2017). In monetary economics, the quantity theory of money is based on the idea that demand and supply of money determine the price level. Using this framework, Buchholz et al. (2012) highlighted that the demand and supply forces is one of the crucial drivers of Bitcoin price. Besides, NaiFovino, et al. (2015) and Ciaian et al. (2018) emphasized the correlation between macrofinancial indicators and Bitcoin prices using Keynesian theory of speculative demand for money framework. The theory stated that market participants hold currency for circumventing a capital loss from investments in financial assets such as bonds and stocks. An increase in the interest rate causes the drop in the financial asset prices, thereby resulting in a capital loss (negative returns) from holding financial assets (Keynes, 1936). Hence, the traders may desire to hold virtual currency as a safe haven to avoid such losses from the financial assets. In contrast, Kristoufek (2013) postulated that the price valuation of Bitcoin cannot be determined by market forces and macro-financial indicators due to the fact that Bitcoin markets are not centrally regulated unlike conventional fiat currencies. Similarly, Bouoiyour and Selmi (2015) established the evidence that Bitcoin is isolated from the macroeconomic fundamentals and acts as a speculative asset.

Several empirical literatures have attempted to uncover the mechanisms behind cryptocurrency pricing. Still there is no consensus about the factors influencing real value of cryptocurrencies that can direct investment decision making. Prior research on Bitcoin-macrofinancial indicators nexus emphasize that the Bitcoin should be treated as a diversifier, hedge or a safe haven (Popper 2015; Dyhrberg 2016 and Bouri et al. 2017) rather than a speculative asset (Glaser et al. 2014; Ciaian et al. 2016a; Bouri et al. 2017 and Zhu et al. 2017). However, the ability of the Bitcoins to protect investors during the market turmoil has become a question as its price has moved in tandem with risky assets viz. stock indexes, commodity indexes, gold, oil and the US dollar index.

Figure 1 shows a negative correlation between Bitcoin and Gold, which implies that Bitcoin can be used as good hedge against the adverse price movements of gold. This low correlation also implies that Bitcoin offers large diversification benefits. Similarly, the authors have ascertained a negative correlation between S\&P GSCI commodity market index and Bitcoin price as indicated in Figure 2.

The strong positive correlation between the DJIA stock market index and Bitcoin price in Figure 3 indicates that both the assets are largely considered as a speculative tools rather than a hedging devices.

Figure 4 shows a negative relationship between Crude Oil and Bitcoin prices. This implies that digital coin has hedging ability to reduce the risk against downward trend of crude oil prices. 
SRINIVASAN, MAITY, KUMAR Macro-Financial Parameters and Bitcoin Prices

Figure 1. Bitcoin and Gold price

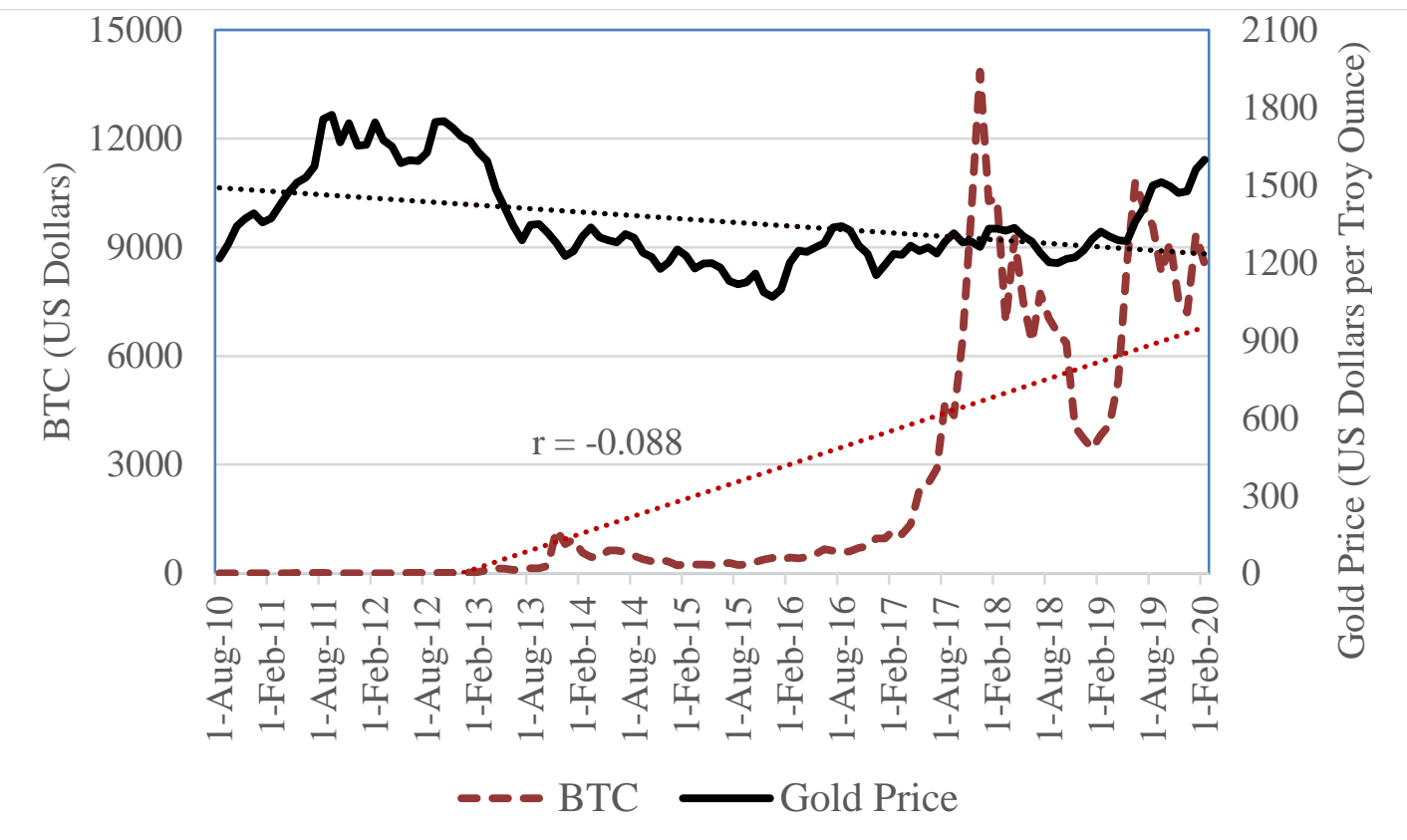

Figure 2. Bitcoin price and S\&P GSCI commodity market index

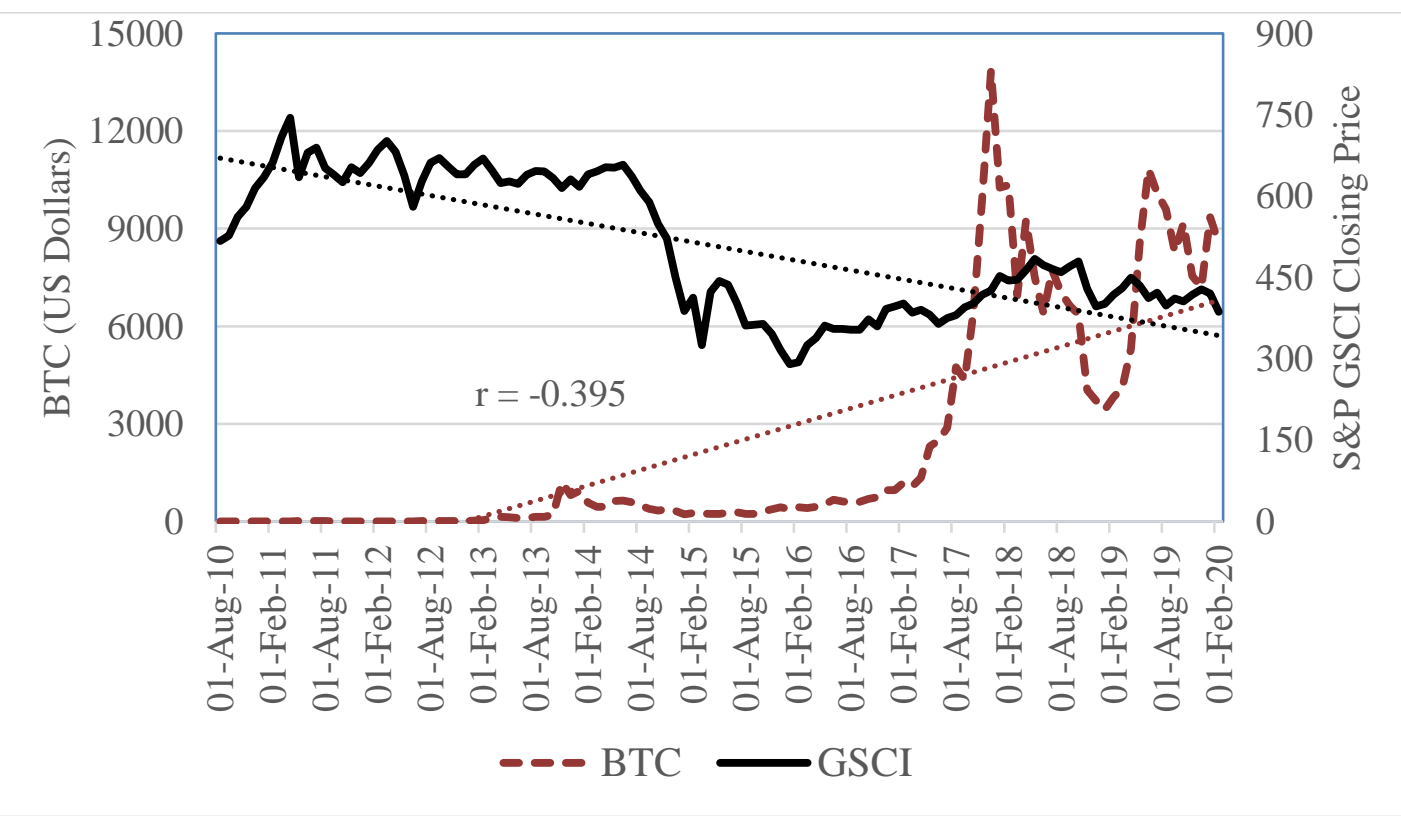


Review of Economic Analysis 14 (2022) 143-175

Figure 3. Bitcoin price and DJIA stock market index

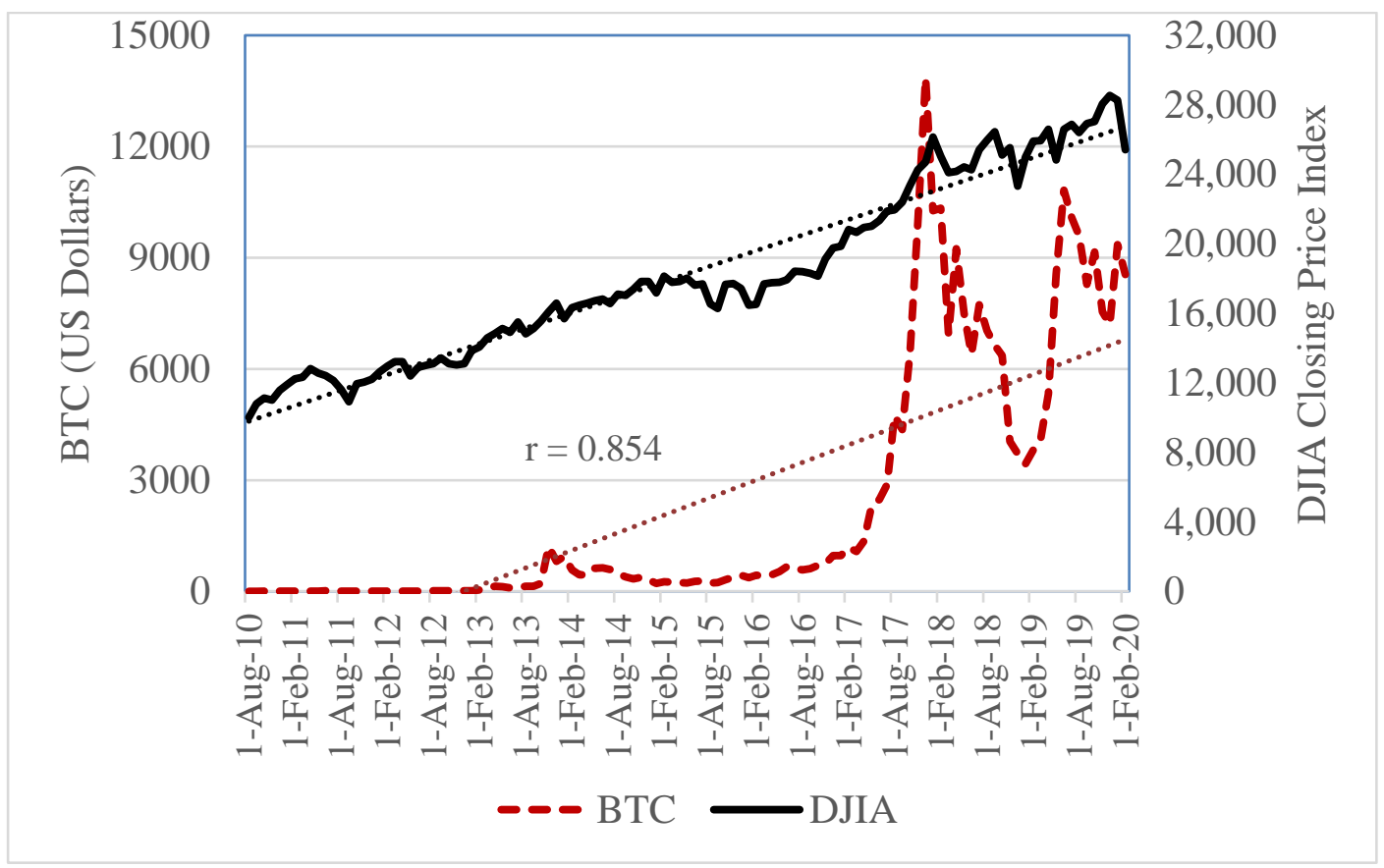

Figure 4. Bitcoin price and Brent crude oil price

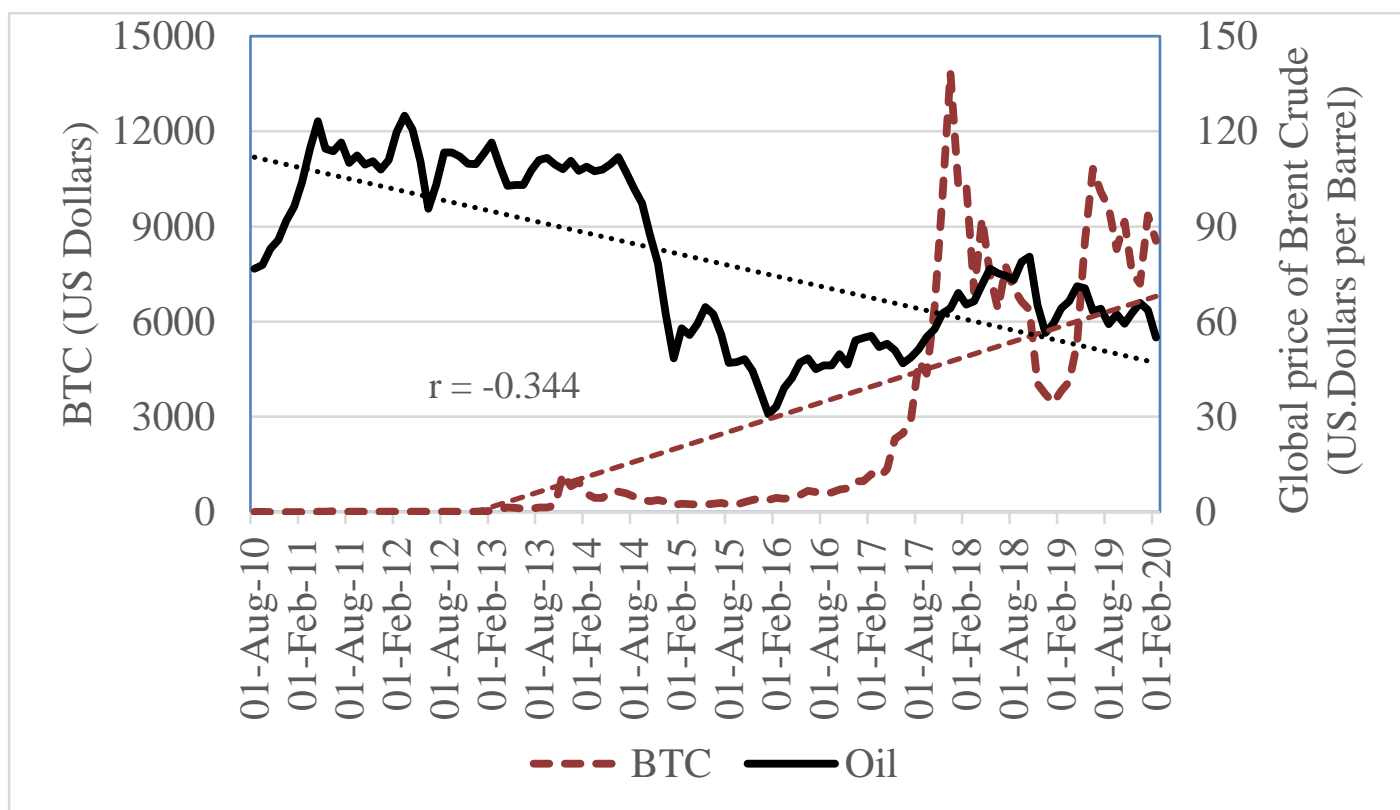


Figure 5 shows positive relationship between US dollar index and Bitcoin prices. Bitcoin and US dollar index has no or limited intrinsic value and largely fails to satisfy the criteria for being a fiat currency. The positive movements imply that both assets are largely considered as speculative tools rather than a hedging devices.

We found strong positive correlation between inflation and Bitcoin prices in Figure 6. This shows that Bitcoin is used for transaction purpose despite of soaring prices of goods and services. The fact that the value of Bitcoin is not regulated by the central bank that constitutes a major difference to standard currencies. For instance, the US Federal Reserve Bank withdraws dollars from circulation in order to control inflation, in contrast, the supply of Bitcoin evolves due to decentralized computing activities of miners' increases the ability of digital coin as a transaction medium. Hence, a conventional tool for promoting price stability is inaccessible for cryptocurrencies.

It is perceived that there is a strong positive correlation between Federal funds rate and Bitcoin prices as evident from Figure 7. Bitcoin has been perceived as speculative or store of value asset against rise in the Federal funds rate. If the Federal Reserve enacts higher interest rates, the Bitcoin price may surges as investors move their money out of speculative investments such as bonds. Moreover, the Bitcoin is considered as a private, decentralized digital currency and its feature forces all investors and traders in a block chain network to trust each other, instead of trusting on a third-party (central authority) that may not always have the best interests. This could result in investors parking their savings in a digital store of value asset.

Figure 5. Bitcoin price and US dollar index

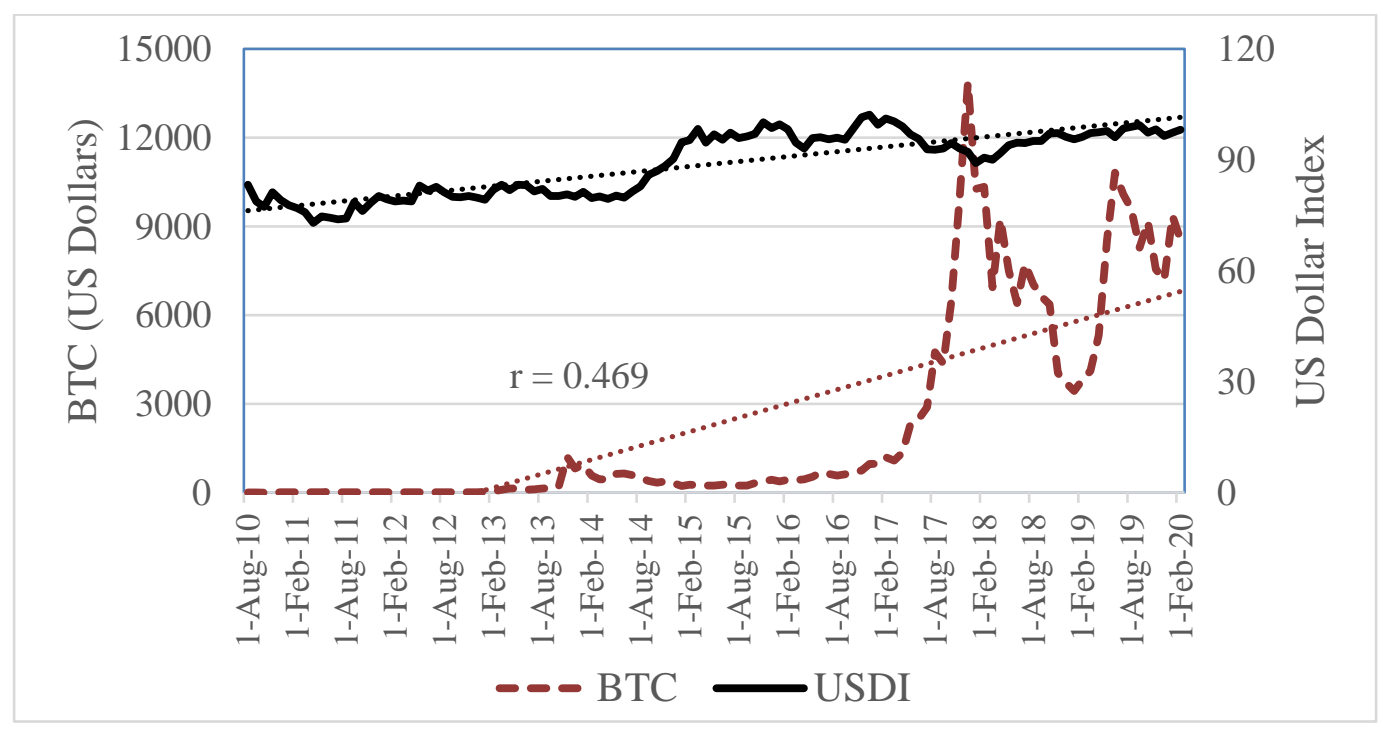


Review of Economic Analysis 14 (2022) 143-175

Figure 6. Bitcoin price and CPI

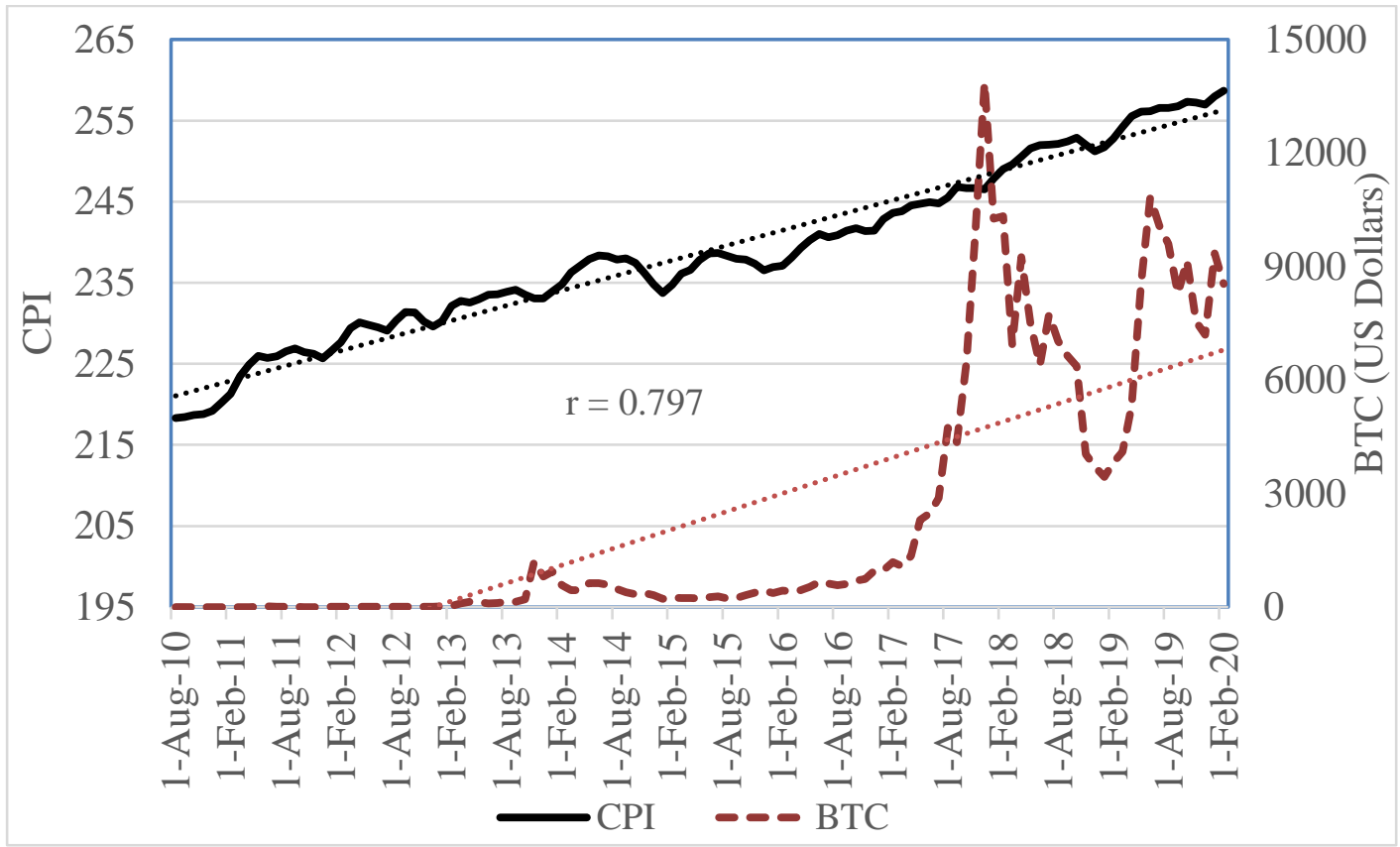

Figure 7. Bitcoin price and Federal funds rate

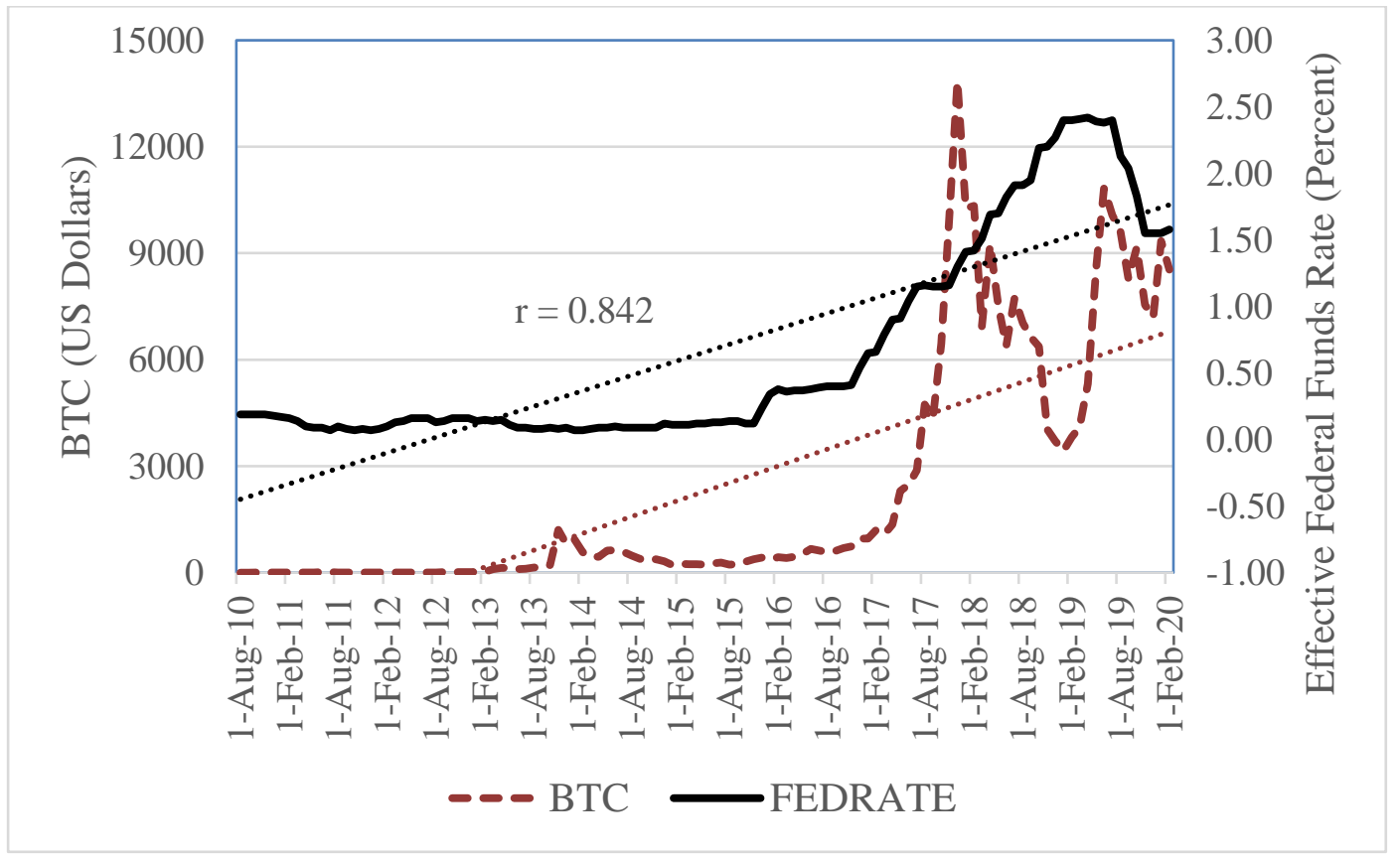


In addition to graphical representation, the present study attempts to examine the impact of macro-financial indicators on Bitcoin price using symmetric and asymmetric autoregressive distributed lag model (ARDL) models. Our study addresses the research questions that (1) whether macro-financial indicators influence Bitcoin price and to what extent? (2) Is Bitcoin a hedge or safe haven tool or simply a speculative investment asset with reference to various risky assets? Understanding the competences of Bitcoin in the current block chain ecosystem is significant for financial market participants who seek protection against market turmoil and adverse price movements.

\section{Literature Review}

Prior literature on nexus between macro-financial factors and cryptocurrencies markets postulated that the assimilation between the Bitcoin and other financial assets is a dynamic process that differs over time. A pioneering study by Wijk (2013) investigated the association between Bitcoin and macro-financial developments such as stock indices, exchange rates and oil prices. He found that the Dow Jones index, the euro-dollar exchange rate and oil price had a significant impact on the Bitcoin prices in the long run. Using error correction model, Zhu et al. (2017) investigated how economic factors viz. Custom price index, US dollar index, Dow jones industry average, Federal Funds Rate and gold price influence Bitcoin price. The authors found that these factors had a long-term influence on Bitcoin price. Ciaian et al. (2018) applied the Autoregressive Distributed Lag (ARDL) for the daily data of 17 virtual currencies and showed that macro-financial indicators influence the altcoin price formation to a larger extent than the Bitcoin in the long-run. Samah et al. (2018) studied the association between bitcoin, exchange rates of US Dollar in JPY, GBP and CNY and gold prices using GARCH-type models. The results indicated a significant relationship between Bitcoin, exchange rate and gold prices.

Das and Kannadhasan (2018) examined the association between Bitcoin prices and global factors viz. stock index, economic policy uncertainty, gold spot prices and implied volatility and crude oil prices using wavelet-based analysis. They ascertained a significant multi-scale interactive behavior of bitcoin with global factors in the medium to long-run and not in the short-run. Using ARDL model, Bouri et al. (2018) identified that the Bitcoin price movements can be predicted based on commodity price and gold prices. Sukamulja and Sikora (2018) studied the factors that influence the price movement of bitcoin using error correction model, impulse response function and variance decomposition analysis. The results obtained from their study indicated that the macroeconomic indicators and the demand for Bitcoins influence the Bitcoin price fluctuations in the short-run and long-run.

Kjaerland et al. (2018) applied the ARDL and GARCH models and showed that the Bitcoin prices are influenced by the S\&P 500 returns and Google searches. Moreover, the findings indicated that $\mathrm{CBOE}$ volatility index (VIX), oil price, gold price and Bitcoin transaction volume 
to be insignificant. İçellioğlua and Öner (2019) studied the effects of S\&P 500 stock market index, gold price, oil price, two-year benchmark US Bond interest rate and US Dollar index on prices of four major cryptocurrencies, viz. Bitcoin, Litecoin, Ethereum, and Ripple. They applied panel data analysis and showed that increase in gold price, oil price and S\&P 500 index leads to increase in the prices of cryptocurrencies, while increase in two-year benchmark US Bond interest rate and US Dollar index leads to decrease in the prices of cryptocurrencies. By applying error correction model, Andrean et al. (2019) examined the response of bitcoin prices to the shock from GDP, inflation, exchange rate and JCI (Jakarta Composite Index). They found that macroeconomic factors had a significant effect on bitcoin prices. Kusumastuty et al. (2019) demonstrated the influence of monetary variables on cryptocurrency price using Vector Autoregression (VAR) model and indicated that there is no significant influence of monetary variables on the cryptocurrency prices in the initial phase. However, the results in the later phases indicated a significant relationship.

Zwick and Syed (2019) employed threshold regression model and established that gold is a significant predictor of Bitcoin prices. Moreover, Adebola et al. (2019) investigated the connection between cryptocurrencies and gold prices and ascertained co-integration for few cryptocurrencies. By employing the Bayesian structural time series approach, Poyser (2019) identified that Bitcoin price is related with the macroeconomic variables. Tiwari et al. (2019) examined the time-varying correlations between six cryptocurrency and S\&P 500 index markets using a copula-ADCC-EGARCH model. They found that the time-varying correlations are very low, indicating that cryptocurrency serves as a hedge asset against the risk of S\&P 500 stock market. Kurka (2019) acknowledged the connectedness between cryptocurrencies and traditional assets is negligible. Ünvana (2019) analysed the impact of Bitcoin prices on major stock indexes using error correction model and Granger causality analysis. The author found significant causation among the variables. Recently, Corbet et al. (2020) assessed the relationship between macroeconomic news coverage and Bitcoin returns using regression model and found that the news relating to unemployment and durable goods announcements are found to have significant effect on Bitcoin returns. News relating to GDP and consumer price index do not have significant impact on Bitcoin returns.

Ciaian et al. (2016b) examined the traditional determinants of Bitcoin price using the conceptual framework based on the Barro (1979) model. They found that macro-financial developments do not have significant effect on Bitcoin price in the long run. Ji et al. (2018) examined the contemporaneous and lagged relations between Bitcoin and other asset classes and found that the investment assets do not plays a dominant role in determining the Bitcoin market. Pyo and Lee (2019) analyzed the impact of FOMC (Federal Open Market Committee) and macroeconomic news announcements on Bitcoin prices using GARCH model. They found that FOMC announcements had significant effect but the Bitcoin price change was quite secluded from the announcement of macroeconomic news. Gurrib et al. (2019) studied whether 
the returns of top market capitalized cryptocurrencies are influenced by the major global macroeconomic news using a vector autoregressive (VAR) model and found macroeconomic news announcement do not exert significant influence on major cryptocurrencies except Monero.

Goczek and Skliarov (2019) applied vector error correction (VEC) model and concluded that the commodity and stock markets exert a positive impact on Bitcoin price but not robust. Panagiotidis et al. (2019) examined the effects of macroeconomic factors such as stock market returns, exchange rates, gold and oil returns, federal funds rate, external commercial borrowing rate and internet trends on bitcoin returns. Using VAR models and impulse response functions, the authors found a significant interaction between Bitcoin price and major stock markets, but weaker interaction with macroeconomic factors. Canh et al. (2019) examined the relationship between the prices of leading seven cryptocurrencies and economic factors viz. oil price, gold price, interest rate, US dollar and S\&P500. The authors applied Granger causality and GARCHtype approaches for the weekly data of Bitcoin, Litecoin, Ripple, Stellar, Monero, Dash, and Bytecoin and found that economic factors do not exert significant influences on virtual currencies.

Nguyen et al. (2019) examined the asymmetric impacts of monetary policies on cryptocurrency returns during monetary tightening and monetary easing regimes using the Generalised Method of Moments (GMM) model. The results revealed a significant responses of four major cryptocurrencies to Chinese tightening monetary policies. However, the US monetary policies do not significantly influenced the cryptocurrency returns. Using a decision tree method, Bayramoğlu and Başarır (2019) investigated the relationship between Bitcoin, S\&P 500 stock index, gold prices, oil prices, Euro/Dollar exchange rate and FED Treasury bill interest rate. The experimental results showed that macro-financial indicators do not have significant effect on the Bitcoin price except S\&P 500 index. Recently, Charfeddine et al. (2020) used different time-varying copula approaches and bivariate dynamic conditional correlation GARCH models and established the evidence of weak cross-correlation between the crytocurrencies and conventional assets.

Earlier studies had investigated the symmetric (linear) relation between cryptocurrency price and macroeconomic-finance indicators using various econometric approaches viz. ARCH and GARCH models, Johansen co-integration techniques, VAR models and VEC models. These techniques investigate the short-term and long-term relationship between regressors and regress and without taking into account the asymmetric effect for Bitcoin modelling. Corbet et al. (2020) pointed out that the Bitcoin price series respond asymmetrically to positive and negative changes in the macroeconomic-financial indicators. Moreover, the pioneering work by Bouri et al. (2018) emphasized to apply non-standard (asymmetric) co-integration models to uncover the intricacy and concealed relations between Bitcoin and asset classes. This incites to develop a dynamic empirical technique investigating this asymmetrical impact on the 
Bitcoin prices. Moreover, the earlier studies do not account for potential structural breaks in Bitcoin price series which can lead to the biased results when conducting econometric analysis. It was also ascertained that the previous literature focused only on specific macroeconomic and financial indicators to examine the determinants of Bitcoin prices and ignored the significant factors such as transaction volume, hash rate and investor's attractiveness. This could leads to biased inference and inaccurate policy recommendations. Therefore, a broad-based analysis is desirable to ensure a correct statistical inference.

To address the gaps in the literature, this study attempts to examine the impact of macroeconomic-financial indicators on Bitcoin price using symmetric and asymmetric version of autoregressive distributed lag model (ARDL) models with structural breaks. Further, the authors have incorporated the key internal driving forces of Bitcoin price viz. the total USD value trading volume on major bitcoin exchanges (trade volume), the number of transactions per day which account for unique trades per day excluding the100 most popular addresses (network activity), the power of miner's machines (hash rate) and investor's attractiveness (Google trends) to provide a more comprehensive model of linking cryptocurrency market and macroeconomic-financial indicators. The information bestowed in this work could be useful for investors and regulators, those who have taken real-time interest in this type of cryptocurrency. Most importantly, armed with knowledge of Bitcoin as a diversifier, hedge or a safe haven against macroeconomic and financial assets, the Bitcoin users and traders can make the investment decisions.

\section{Data and Methodology}

\subsection{Data}

The present study is focused on data which has been compiled on a monthly basis for the period from August 2010 to February 2020. The oil prices (Global price of Brent Crude, US Dollars per Barrel), stock market index (DJIA), represented by the Dow Jones Industrial Average Index, Consumer Price Index, Effective Federal Funds Rate, US Dollar Index (USDI), the gold price in London Bullion Market based in US Dollars (US Dollars per Troy Ounce) and S\&P GSCI Commodity market index are extracted from the Federal Research Bank of St. Louis (https://research.stlouisfed.org). The Bitcoin price (BTC), denominated in US Dollars are extracted from http://bitcoincharts.com.

Following Poyser (2017), the authors have incorporated three types of platform descriptors as the control variables viz. Currency statistics, Mining information and Network activity. For currency statistics, the authors have included the USD exchange trade volume (VOL) that represents the total USD value trading volume on major Bitcoin exchanges. Regarding the mining information, the authors have included the hash rate (HASHRATE) that measures the power of miner's machines. In order to capture the network activity (TRANS), 


\section{SRINIVASAN, MAITY, KUMAR Macro-Financial Parameters and Bitcoin Prices}

the number of transactions per day is considered which accounts for unique trades per day excluding the 100 most popular addresses. For this study the data is obtained from Quandl.com. Following Kristoufek (2013) and Kjaerland et al (2018), the authors have used queries of Bitcoin on Google Trends to measure investor attractiveness/sentiment in BitCoin. These data are available at https://trends.google.com/trends/explore?date=all\&q=bitcoin.

\subsection{Methodology}

The symmetric ARDL and asymmetric ARDL techniques are applied to examine the impact of macroeconomic-financial indicators on Bitcoin price. The general form of the symmetric ARDL method proposed by Pesaran et al. $(1996,2001)$ takes the following form:

$\Delta \ln B_{T}=C_{t}+\sum_{i=1}^{n} \alpha_{1} \Delta \ln B T C_{t-1}+\sum_{i=1}^{n} \alpha_{2} \Delta \ln C P I_{t-1}+\sum_{i=1}^{n} \alpha_{3} \Delta \ln D J I A_{t-1}+\sum_{i=1}^{n} \alpha_{4} \Delta \ln F E D R R A T E_{t-1}+$ $\sum_{i=1}^{n} \alpha_{5} \Delta \ln$ OIL $_{t-1}+\sum_{i=1}^{n} \alpha_{6} \Delta \ln U S D I_{t-1}+\sum_{i=1}^{n} \alpha_{7} \Delta \ln G O L D_{t-1}+\sum_{i=1}^{n} \alpha_{8} \Delta \ln G S C I_{t-1}+\sum_{i=1}^{n} \alpha_{9} \Delta \ln H A S H R A T E_{t-1}+$ $\sum_{i=1}^{n} \alpha_{10} \Delta \ln V O L_{t-1}+\sum_{i=1}^{n} \alpha_{11} \Delta \ln T_{R A N S_{t-1}}+\sum_{i=1}^{n} \alpha_{12} \Delta \ln G O O G L E_{t-1}+\beta_{1} \ln B T C_{t-1}+\beta_{2} \ln C P I_{t-1}+\beta_{3} \ln D J I A_{t-1}$ $\beta_{4} \ln$ FEDRATE $_{t-1}+\beta_{5} \ln$ OIL $_{t-1}+\beta_{6} \ln U S D I_{t-1}+\beta_{7} \ln$ OOLD $_{t-1}+\beta_{8} \ln$ GSCI $_{t-1}+\beta_{9} \ln$ HASHRATE $_{t-1}$ $+\beta_{10} \ln V O L_{t-1}+\beta_{11} \ln \operatorname{TRANS}_{t-1}+\beta_{12} \ln G O O G L E_{t-1}+\varepsilon_{1 t}$

where $\ln$ is the natural $\log$ and $\Delta$ is the first difference operator. The long-run association between proposed variables are examined using equation (1). As stated in Pesaran and Pesaran (1997), the F-statistic is used to test the existence of long run relationship under the null hypothesis of no cointegration $\left(\beta_{1}=\beta_{2}=\beta_{3}=\beta_{4}=\beta_{5}=\beta_{6}=\beta_{7}=\beta_{8}=\beta_{9}=\beta_{10}=\beta_{11}=\beta_{12}=0\right)$ against the alternative hypothesis of presence of cointegration $\left(\beta_{1} \neq \beta_{2} \neq \beta_{3} \neq \beta_{4} \neq \beta_{5} \neq \beta_{6} \neq \beta_{7} \neq \beta_{8} \neq \beta_{9} \neq\right.$ $\beta_{10} \neq \beta_{11} \neq \beta_{12} \neq 0$ ), which is referred to as (F $F_{\text {вTC }} \mid$ BTC, CPI, DJIA, FEDRATE, OIL, USDI, GOLD, GSCI, HASHRATE, VOL, TRANS, GOOGLE). If the estimated F-statistic is higher than the upper bound of the critical value, then there exists a stable long run relationship.

The ARDL specification of the error correction model are formulated as follows:

$$
\begin{aligned}
& \Delta \ln \text { BTC }_{t}=\alpha_{o}+\sum_{i=1}^{n} \alpha_{1} \Delta \ln \text { BTC }_{t-1}+\sum_{i=1}^{n} \alpha_{2} \Delta \ln C P I_{t-1}+\sum_{i=1}^{n} \alpha_{3} \Delta \ln \text { DJIA }_{t-1}+\sum_{i=1}^{n} \alpha_{4} \Delta \ln \text { FEDRRATE }_{t-1}+ \\
& \sum_{i=1}^{n} \alpha_{5} \Delta \ln \text { OIL }_{t-1}+\sum_{i=1}^{n} \alpha_{6} \Delta \ln \text { USDI }_{t-1}+\sum_{i=1}^{n} \alpha_{7} \Delta \ln G O L D_{t-1}+\sum_{i=1}^{n} \alpha_{8} \Delta \ln G S C I_{t-1}+\sum_{i=1}^{n} \alpha_{9} \Delta \ln \text { HASHRATE }_{t-1}+ \\
& \sum_{i=1}^{n} \alpha_{10} \Delta \ln \text { VOL }_{t-1}+\sum_{i=1}^{n} \alpha_{11} \Delta \ln \operatorname{TRANS}_{t-1}+\sum_{i=1}^{n} \alpha_{12} \Delta \ln \text { GOOGLE} E_{t-1}+\gamma_{1} Z_{t-1}+\varepsilon_{1 t}
\end{aligned}
$$


Review of Economic Analysis 14 (2022) 143-175

In the above equation (2), $\gamma_{1}$ is the error correction term and $\alpha$ s are the short-run parameters and $\varepsilon_{\mathrm{t}}$ are assumed to be stationary random processes with a mean of zero and constant variance. Under equation (2), the short-run effect is assessed based on the significance of the coefficients of each lagged endogenous variable.

Shin et al. (2014) have recently developed the asymmetric ARDL model using negative and positive partial sum decompositions that allow to identify the asymmetric effect in short run and long run. As the asymmetric ARDL approach is an extension of the symmetric ARDL cointegration model, we incorporated the decomposed negative and positive series of exogenous variables to make the asymmetric ARDL specification.

$\Delta \ln B T C_{t}=\alpha_{o}+\sum_{i=1}^{n} \alpha_{1} \Delta \ln B T C_{t-1}+\sum_{i=1}^{n} \alpha_{2} \Delta \ln C P I_{t-1}^{+}+\sum_{i=1}^{n} \alpha_{3} \Delta \ln C P I_{t-1}^{-}+\sum_{i=1}^{n} \alpha_{4} \Delta \ln D J I A_{t-1}^{+}+$ $\sum_{i=1}^{n} \alpha_{5} \Delta \ln D J I A_{t-1}^{-}+\sum_{i=1}^{n} \alpha_{6} \Delta \ln F E D R A T E_{t-1}^{+}+\sum_{i=1}^{n} \alpha_{7} \Delta \ln F E D R A T E_{t-1}^{-}+\sum_{i=1}^{n} \alpha_{8} \Delta \ln O I L_{t-1}^{+}+\sum_{i=1}^{n} \alpha_{9} \Delta \ln O I L_{t-1}^{-}+$ $\sum_{i=1}^{n} \alpha_{10} \Delta \ln U S D I_{t-1}^{+}+\sum_{i=1}^{n} \alpha_{11} \Delta \ln U S D I_{t-1}^{-}+\sum_{i=1}^{n} \alpha_{12} \Delta \ln G O L D_{t-1}^{+}++\sum_{i=1}^{n} \alpha_{13} \Delta \ln G O L D_{t-1}^{-}++\sum_{i=1}^{n} \alpha_{14} \Delta \ln G S C I_{t-1}^{+}+$ $\sum_{i=1}^{n} \alpha_{15} \Delta \ln \operatorname{GSCI}_{t-1}^{-}+\sum_{i=1}^{n} \alpha_{16} \Delta \ln H A S H R A T E_{t-1}^{+}+\sum_{i=1}^{n} \alpha_{17} \Delta \ln \operatorname{HASHRATE}_{t-1}^{-}+\sum_{i=1}^{n} \alpha_{18} \Delta \ln \operatorname{VOL}_{t-1}^{+}+$ $\sum_{i=1}^{n} \alpha_{19} \Delta \ln V O L_{t-1}^{-}+\sum_{i=1}^{n} \alpha_{20} \Delta \ln \operatorname{TRANS}_{t-1}^{+}+\sum_{i=1}^{n} \alpha_{21} \Delta \ln \operatorname{TRANS}_{t-1}^{-}+\sum_{i=1}^{n} \alpha_{22} \Delta \ln G O O G L E_{t-1}^{+}+\sum_{i=1}^{n} \alpha_{23} \Delta \ln G O O G L E_{t-1}^{-}+$ $\beta_{1} \ln B T C_{t-1}+\beta_{2} \ln C P I_{t-1}^{+}+\beta_{3} \ln C P I_{t-1}^{-}+\beta_{4} \ln D J I A_{t-1}^{+}+\beta_{5} \ln D J I A_{t-1}^{-}+\beta_{6} \ln F E D R A T E_{t-1}^{+}+\beta_{7} \ln F E D R A T E_{t-1}^{-}$ $+\beta_{9} \ln O I L_{t-1}^{+}+\beta_{10} \ln O I L_{t-1}^{-}+\beta_{11} \ln U S D I_{t-1}^{+}+\beta_{12} \ln U S D I_{t-1}^{-}+\beta_{13} \ln G O L D_{t-1}^{+}+\beta_{14} \ln G O L D_{t-1}^{-}+\beta_{15} \ln G S C I_{t-1}^{+}$ $+\beta_{16} \ln \mathrm{GSCI}_{t-1}^{-}+\beta_{17} \ln H A S H R A T E_{t-1}^{+}+\beta_{18} \ln H A S H R A T E_{t-1}^{-}+\beta_{19} \ln V_{O L L_{t-1}^{+}}^{+} \beta_{20} \ln V_{\text {OL }}^{-}+\beta_{21} \ln \operatorname{TRANS}_{t-1}^{+}$ $+\beta_{22} \ln T R A N S_{t-1}^{-}+\beta_{23} \ln G O O G L E_{t-1}^{+}+\beta_{24} \ln G O O G L E_{t-1}^{-}+\varepsilon_{1 t}$

To evaluate the performance of the estimated symmetric and asymmetric ARDL models, the various diagnostic tests are conducted to examine the serial correlation, functional form, nonnormality and heteroscedasticity. Furthermore, the study also conduct the stability tests 
proposed by Brown et al. (1975), namely, CUSUM (Cumulative Sum) and CUSUMSQ (CUSUM of Squares) of recursive residuals. The null hypothesis of instability is rejected when the plots of the CUSUM and the CUSUMSQ stay within the five percent significance level.

\section{Results and Discussion}

\subsection{Unit root test}

Perron (1989) and Leybourne and Newbold (2003) emphasized that the evidences obtained from the traditional unit root tests viz. augmented Dickey-Fuller test (ADF), Phillips-Perron test (PP) and Kwiatkowski-Phillips-Schmidt-Shin (KPSS) test may be biased towards the rejection the null hypothesis of a unit root when there is a structural break in a time series. Hence, Perron (1989) proposed modified Dickey-Fuller test by including dummy variables to account for a structural shift under two forms, viz. the additive outlier (AO) model and the innovative outlier (IO) model, that captures the immediate and gradual shocks, respectively. The results of breakpoint unit root test are shown in Table 1. The empirical results reveal that the macro-financial variables are found to be stationary either at level, $\mathrm{I}(0)$ or first difference, $\mathrm{I}(1)$ indicating the order of integration is a mixture of $\mathrm{I}(0)$ and $\mathrm{I}(1)$, thus makes ARDL the preferred approach.

Table 1. Unit root test with a breakpoint

\begin{tabular}{|c|c|c|c|c|c|}
\hline \multirow[t]{2}{*}{ Variables } & Level & \multirow[t]{2}{*}{$\mathrm{TB}_{1}$} & $\begin{array}{c}\text { First } \\
\text { Difference }\end{array}$ & \multirow[t]{2}{*}{$\mathrm{TB}_{1}$} & \multirow[t]{2}{*}{$\begin{array}{l}\text { Order of } \\
\text { Integration }\end{array}$} \\
\hline & t-statistics & & t-statistics & & \\
\hline \multicolumn{6}{|c|}{ Innovative Outlier (IO) model } \\
\hline BTC & $\begin{array}{c}-3.29473 \\
(0.5063)\end{array}$ & Sep 2016 & $\begin{array}{c}-10.0601 * \\
(<0.01)\end{array}$ & Nov 2013 & $\mathrm{I}(1)$ \\
\hline CPI & $\begin{array}{r}-2.68675 \\
(0.8355)\end{array}$ & Feb 2016 & $\begin{array}{l}-7.62879 * \\
(<0.01)\end{array}$ & Mar 2012 & $\mathrm{I}(1)$ \\
\hline DJIA & $\begin{array}{l}-3.08569 \\
(0.6362)\end{array}$ & Feb 2016 & $\begin{array}{l}-12.2563^{*} \\
(<0.01)\end{array}$ & Feb 2016 & $\mathrm{I}(1)$ \\
\hline FEDRATE & $\begin{array}{l}-4.72496 * * \\
(0.0226)\end{array}$ & Nov 2015 & -- & -- & $\mathrm{I}(0)$ \\
\hline OIL & $\begin{array}{c}- \\
4.30306^{* * *} * \\
(0.0741)\end{array}$ & Sep 2014 & -- & -- & $\mathrm{I}(0)$ \\
\hline USDI & $\begin{array}{l}-4.63006^{* *} \\
(0.0300)\end{array}$ & Aug 2014 & -- & -- & $\mathrm{I}(0)$ \\
\hline GOLD & $\begin{array}{r}-3.32859 \\
(0.4873) \\
\end{array}$ & Jan 2013 & $\begin{array}{l}-8.93371^{*} \\
(<0.01)\end{array}$ & Aug 2011 & $\mathrm{I}(1)$ \\
\hline
\end{tabular}


Review of Economic Analysis 14 (2022) 143-175

\begin{tabular}{|c|c|c|c|c|c|}
\hline GSCI & $\begin{array}{l}-4.55920 * * \\
(0.0369) \\
\end{array}$ & Sep 2014 & -- & -- & $\mathrm{I}(0)$ \\
\hline HASHRATE & $\begin{array}{c}- \\
4.19856^{* * * *} \\
(0.0987)\end{array}$ & Feb 2013 & - & - & $\mathrm{I}(0)$ \\
\hline VOL & $\begin{array}{r}-4.12445 \\
(0.1190)\end{array}$ & May 2015 & $\begin{array}{l}-15.8143^{*} \\
(<0.01)\end{array}$ & Apr 2011 & $\mathrm{I}(1)$ \\
\hline TRANS & $\begin{array}{r}-3.63628 \\
(0.3134)\end{array}$ & Nov 2010 & $\begin{array}{l}-12.2663^{*} \\
(<0.01)\end{array}$ & June 2011 & $\mathrm{I}(1)$ \\
\hline GOOGLE & $\begin{array}{l}-10.4971 * \\
(<0.01)\end{array}$ & Dec 2017 & -- & -- & $\mathrm{I}(0)$ \\
\hline \multicolumn{6}{|c|}{ Addictive Outlier (AO) model } \\
\hline BTC & $\begin{array}{r}-3.23744 \\
(0.5438)\end{array}$ & Sep 2016 & $\begin{array}{l}-9.44762 * \\
(<0.01)\end{array}$ & June 2011 & $\overline{\mathrm{I}(1)}$ \\
\hline CPI & $\begin{array}{r}-2.18107 \\
(0.9652)\end{array}$ & Nov 2015 & $\begin{array}{c}-7.70668^{*} \\
(<0.01)\end{array}$ & Nov 2014 & $\mathrm{I}(1)$ \\
\hline DJIA & $\begin{array}{c}-3.05838 \\
(0.6517)\end{array}$ & Jan 2020 & $\begin{array}{c}-12.5648^{*} \\
(<0.01)\end{array}$ & Jan 2020 & $\mathrm{I}(1)$ \\
\hline FEDRATE & $\begin{array}{r}-3.16594 \\
(0.5871)\end{array}$ & Dec 2015 & $\begin{array}{c}-10.2394^{*} \\
(<0.01)\end{array}$ & Dec 2015 & $\mathrm{I}(1)$ \\
\hline OIL & $\begin{array}{c}- \\
4.27366^{* * * *} \\
(0.0793)\end{array}$ & Aug 2014 & -- & -- & $\mathrm{I}(0)$ \\
\hline USDI & $\begin{array}{l}-4.65442 * * \\
(0.0281)\end{array}$ & Aug 2014 & - & -- & $\mathrm{I}(0)$ \\
\hline GOLD & $\begin{array}{r}-3.25435 \\
(0.5381) \\
\end{array}$ & Jan 2013 & $\begin{array}{l}-9.00618^{*} \\
(<0.01)\end{array}$ & Aug 2011 & $\mathrm{I}(1)$ \\
\hline GSCI & $\begin{array}{r}-3.70825 \\
(0.2788)\end{array}$ & Apr 2014 & $\begin{array}{c}-11.2128^{*} \\
(<0.01)\end{array}$ & May 2011 & $\mathrm{I}(1)$ \\
\hline HASHRATE & $\begin{array}{r}-4.06422 \\
(0.1359) \\
\end{array}$ & Feb 2020 & $\begin{array}{c}-8.64738^{*} \\
(<0.01)\end{array}$ & June 2011 & $\mathrm{I}(1)$ \\
\hline VOL & $\begin{array}{c}-4.02754 \\
(0.1479)\end{array}$ & Apr 2015 & $\begin{array}{c}-15.9468^{*} \\
(<0.01)\end{array}$ & Apr 2011 & $\mathrm{I}(1)$ \\
\hline TRANS & $\begin{array}{r}-3.79376 \\
(0.2390) \\
\end{array}$ & Oct 2010 & $\begin{array}{c}-12.3560^{*} \\
(<0.01)\end{array}$ & June 2011 & $\mathrm{I}(1)$ \\
\hline GOOGLE & $\begin{array}{l}-12.8341 * \\
(<0.01)\end{array}$ & Dec 2016 & -- & -- & $\mathrm{I}(0)$ \\
\hline
\end{tabular}

Note: $* * *$ and $* * *$ denotes significance at $1 \%, 5 \%$ and $10 \%$ level, respectively. The lag length was chosen on the basis of the Schwarz Information Criterion. The breakpoint selection method was based on the Dickey Fuller minimization of t-statistic. Figures in brackets are p-values. The reported p-values are asymptotic one-sided p-values and taken from Vogelsang (1993). 
SRINIVASAN, MAITY, KUMAR Macro-Financial Parameters and Bitcoin Prices

\subsection{Structural break analysis}

For robust ARDL approach, the study identified the potential structural breaks in the Bitcoin series using Bai and Perron (1998) test and the results are shown in Table 2. The findings clearly indicate that the significant breakpoints are around March 2013 and May 2017. The significant break that occurred around March 2013 was solely due to bail-in mechanism of Cypriot economy that triggered a wave of bank runs and hunts for monetary safe havens. Bitcoin was considered as an alternative investment that was primarily intended to be uncontrollable by Governments and independent of monetary policies. Therefore, Bitcoin prices have surged in March 2013. In addition, the price increase was driven by prominent Silicon-Valley-based investors and the savvy investors who allegedly involved in market manipulation by recognizing the implications of the Cyprus-Greek crisis and betting on it by bidding on Bitcoin (Gandal et al. 2018).

Another significant break around May 2017 was due to gained momentum in the Bitcoin prices as Japan, Norway and Russia has legitimized the use of cryptocurrencies. Businesses accepting Bitcoin continued to rise and investors are expending Bitcoin as a hedge against broader economic interest. Moreover, the Bitcoin value soared due to active trading among the retail investors, institutional investors, lawmakers and legacy financial companies.

\subsection{ARDL bounds co-integration test}

Prior to applying ARDL bounds co-integration test, it is necessary to determine the appropriate lag length of the macro-financial variables. The results are presented in Table 3. Using optimal lag length criteria viz. final prediction error (FPE) criterion, Schwarz information criterion (SIC) and Hannan-Quinn information criterion, the ARDL $(1,1,1,1,1,1,1,1,1,1,1,1)$ was chosen as the appropriate model for the series.

Gregory et al. (1996) show that conventional co-integration tests are biased towards accepting the null of no-co-integration in the presence of structural breaks. Following Kisswani et al. (2017) and Dube et al. (2018), the study estimates the symmetric and asymmetric ARDL bounds testing approach to co-integration by incorporating the structural breaks that occurred around March 2013 and May 2017. Table 4 show that the computed F-statistics for the symmetric and asymmetric ARDL lies above the upper bound critical values at $1 \%$ and $5 \%$ level of significance, respectively. Therefore, the rejection of null hypothesis supports in favour of long-run relationship between the macroeconomic-financial indicators and Bitcoin prices.

The presence of long-run dynamic relationship between the macroeconomic-financial indicators and Bitcoin price can be further enriched by studying the dynamic multipliers. The dynamic multiplier graph in Appendix 1 presents the asymmetric long-term predictive power of positive and negative changes in macroeconomic and financial indicators. 
Review of Economic Analysis 14 (2022) 143-175

Table 2. Bai-Perron multiple structural breaks test for Bitcoin

\begin{tabular}{|c|c|c|c|}
\hline Break test & F-statistic & Critical value & Break date \\
\hline \hline 0 vs. 1 & $331.4981^{* *}$ & 8.58 & March 2013 \\
1 vs. 2 & $162.4643^{* *}$ & 10.13 & May 2017 \\
2 vs. 3 & 7.63621 & 11.14 & \\
\hline
\end{tabular}

Note: $* *$ denotes significance at 5\% level. The critical values are obtained from the Bai and Perron (2003).

Table 3. Optimal lag length selection criteria

\begin{tabular}{|c|c|c|c|c|c|}
\hline Lag & LR & FPE & AIC & SIC & HQ \\
\hline \hline 0 & --- & $1.39 \mathrm{e}-16$ & -2.45756 & -2.15954 & -2.33673 \\
\hline 1 & 2121.00 & $4.08 \mathrm{e}-25^{*}$ & -22.1172 & $-18.2430^{*}$ & $-20.5464 *$ \\
\hline 2 & 207.824 & $5.25 \mathrm{e}-25$ & -21.9545 & -14.5041 & -18.9336 \\
\hline 3 & $182.828^{*}$ & $7.34 \mathrm{e}-25$ & -21.8629 & -10.8363 & -17.3920 \\
\hline 4 & 141.846 & $1.59 \mathrm{e}-24$ & -21.6004 & -6.99770 & -15.6795 \\
\hline 5 & 149.160 & $2.46 \mathrm{e}-24$ & -22.1073 & -3.92848 & -14.7365 \\
\hline 6 & 157.399 & $2.15 \mathrm{e}-24$ & -23.9378 & -2.18277 & -15.1169 \\
\hline 7 & 165.899 & $5.28 \mathrm{e}-25$ & $-28.4842^{*}$ & -3.15296 & -18.2133 \\
\hline
\end{tabular}

Note: * indicates lag order selected by the criterion. LR, FPE, AIC, SIC and HQ denotes sequential modified likelihood ratio test statistic, final prediction error criterion, Akaike information criterion, Schwarz information criterion and Hannan-Quinn information criterion, respectively.

Table 4. ARDL bounds test for co-integration

\begin{tabular}{|l|l|c|c|}
\hline \multicolumn{4}{|c|}{ Panel A: Symmetric ARDL Model } \\
\hline \hline F-Statistic & K & $99 \%$ Lower bound & $99 \%$ Upper bound \\
\hline $4.756 *^{*}$ & 11 & 2.41 & 3.61 \\
\hline \multicolumn{4}{|c|}{ Panel B: Asymmetric ARDL Model } \\
\hline \hline F-Statistic & K & $95 \%$ Lower bound & $95 \%$ Upper bound \\
\hline $3.4321 * *$ & 22 & 1.98 & 3.04 \\
\hline
\end{tabular}

Note: $*$ and $* *$ denotes significance at $1 \%$ and $5 \%$ level, respectively. The critical values are determined from Pesaran et al. (2001) and Shin et al. (2014). K is the number of regressors in the equation.

Black line indicates the positive impact of the regressors on the regressand while the black dotted line indicates the negative impact. The squat dotted red line shows the asymmetry response. The reedy dotted red lines indicates the upper and the lower bounds of the asymmetry. As regards the consumer price index, the impact of negative changes appears to be positive on the Bitcoin prices. Bitcoin prices respond rapidly and positively to both increases and decreases in Federal Funds rate and impact became smooth after about 4-5 months period corresponding 
to its equilibrium state. We observe that Bitcoin price responds rapidly and positively to both increases and decreases in stock market prices. The impact of positive changes in stock market prices appears to be more pronounced than the negative changes on the Bitcoin prices. Besides, we found that the Bitcoin prices respond rapidly and negatively to decreases in oil price. While the prices respond negatively to increases in US dollar index and impact became smooth after about 3-4 months period. Moving to commodity market price, the impact of negative changes had positive impact on Bitcoin prices and reached the equilibrium state rapidly. It was also found that the Bitcoin price reacts negatively to decrease in the gold price. Finally, we observe that Bitcoin price responds negatively to decrease in internal factors such as network activity, hash rate and Google trends while response are positive to increase in the trade volume.

As the ARDL bounds test and dynamic multiplier analysis confirms the asymmetric cointegration effects of positive and negative changes in macroeconomic and financial indicators on Bitcoin prices, the long-run and short-run estimates of factors influencing the Bitcoin prices are examined using both symmetric and asymmetric ARDL approaches and shown in the Table 5 and Table 6 , respectively.

\subsection{Symmetric ARDL estimates}

Table 5 indicates the result of the long-run and short-run symmetric ARDL approach. Bitcoin prices is used as dependent variable and its global macro-financial determinants are used as independent variables to estimate the long-run and short-run elasticity.

The long-run coefficient of Dow Jones index has positive and significant effect on Bitcoin prices, implying one unit increase in US stock market index will leads to increase in Bitcoin prices by 1.973 units. The positive effect suggest that both assets are largely considered as a speculative tools rather than a hedging device in the long-run. The US dollar index has negative and significant long term influence on Bitcoin prices, implying one unit gain in US dollar index will accompanied by 4.829 units drop in the Bitcoin prices. This implies that Bitcoin can be a hedge against US dollar index in the long-run. However, the CPI, FEDRATE, OIL, GOLD and GSCI do not have significant long-run influences on the Bitcoin price, implying Bitcoin cannot be a hedge against the macroeconomic and financial indicators viz. inflation, federal funds rate, oil price, gold price and commodity market price. In addition, the control (internal) factors viz. trade volume and network activity played a significant role.

The short-run symmetric ARDL shows that the coefficient of the error correction term (ECT) is found to be negative and statistically significant at one percent level implying that the system has the ability to converge back to long-term equilibrium after a short-term shock. The error correction coefficient value signifies that 53 percent of the disequilibria in the Bitcoin prices from the current year's shock can be adjusted in the following period. 
Review of Economic Analysis 14 (2022) 143-175

Table 5. Symmetric ARDL estimates

\begin{tabular}{|c|c|c|c|c|}
\hline \multicolumn{5}{|c|}{ Panel A: Long-run estimates } \\
\hline Variables & Coefficient & Std. Error & t-Statistic & Prob. \\
\hline LnCPI & -7.46149 & 10.0020 & -0.74599 & 0.4577 \\
\hline LnDJIA & $4.69827 *$ & 1.64377 & 2.85821 & 0.0053 \\
\hline LnFEDRATE & -0.03236 & 0.14889 & -0.21738 & 0.8284 \\
\hline LnOIL & 0.37316 & 1.26549 & 0.29487 & 0.7688 \\
\hline LnUSDI & $-4.82950 * * *$ & 2.54379 & -1.89854 & 0.0609 \\
\hline LnGOLD & 0.79941 & 0.88747 & 0.90078 & 0.3702 \\
\hline LnGSCI & -0.04777 & 1.99229 & -0.02397 & 0.9809 \\
\hline LnHASHRATE & -0.01571 & 0.07139 & -0.22008 & 0.8263 \\
\hline LnVOL & $0.22364 *$ & 0.06089 & 3.67238 & 0.0004 \\
\hline LnTRANS & $0.81785^{*}$ & 0.15560 & 5.25604 & 0.0000 \\
\hline GOOGLE & -0.00192 & 0.00657 & -0.29355 & 0.7698 \\
\hline $\mathrm{C}$ & 1.71826 & 45.3023 & 0.03792 & 0.9698 \\
\hline \multicolumn{5}{|c|}{ Panel B: Short-run estimates } \\
\hline Variables & Coefficient & Std. Error & t-Statistic & Prob. \\
\hline$\Delta \mathrm{LnCPI}$ & -7.22432 & 8.43932 & -0.85603 & 0.3943 \\
\hline$\Delta \mathrm{LnDJIA}$ & $1.93738 *$ & 0.66967 & 2.89301 & 0.0048 \\
\hline$\triangle$ LnFEDRATE & -0.13473 & 0.15739 & -0.85605 & 0.3943 \\
\hline$\Delta \mathrm{LnOIL}$ & 0.40552 & 0.51912 & 0.78116 & 0.4368 \\
\hline$\Delta$ LnUSDI & -1.13323 & 1.15753 & -0.97900 & 0.3303 \\
\hline$\Delta$ LnGOLD & 0.25151 & 0.64643 & 0.38907 & 0.6982 \\
\hline$\Delta \mathrm{LnGSCI}$ & -0.36637 & 0.60437 & -0.60620 & 0.5459 \\
\hline$\triangle$ LnHASHRATE & $0.25213^{*}$ & 0.06549 & 3.84990 & 0.0002 \\
\hline$\Delta \mathrm{LnVOL}$ & $0.10354 *$ & 0.02276 & 4.54894 & 0.0000 \\
\hline$\triangle \mathrm{LnTRANS}$ & $0.47735 *$ & 0.09112 & 5.23858 & 0.0000 \\
\hline$\Delta$ GOOGLE & $0.00537 * * *$ & 0.00274 & 1.95887 & 0.0533 \\
\hline $\mathrm{D}_{1}$ & $0.61450 *$ & 0.08711 & 7.05361 & 0.0000 \\
\hline $\mathrm{D}_{2}$ & $0.19334 *$ & 0.05220 & 3.70337 & 0.0004 \\
\hline $\mathrm{ECT}_{\mathrm{t}-1}$ & $-0.53488^{*}$ & 0.06380 & -8.38262 & 0.0000 \\
\hline
\end{tabular}

Note: $*$ and $* * *$ denotes significance at $1 \%$ and $10 \%$ level, respectively.

This indicates that digital coin do not have hedging ability to reduce risk against price movements of US stock market, rather the Bitcoin is treated as speculative tool. However, the other macroeconomic and financial factors do not have significant effect on Bitcoin price in the short-run, hence Bitcoin may not be a hedge against the inflation, US dollar index, federal funds rate, oil price, gold price and commodity market price. This confirms that Bitcoin appears to behave more like a speculative investment than a hedging device. In addition, the results in the table indicates that the structural dummies and internal drivers such as the 
trading volume, network activity, hash rate and Google trends are found to be statistically significant.

\subsection{Asymmetric ARDL estimates}

The authors have further looked into the estimates of the asymmetric ARDL model and the corresponding results are reported in Table 6. From the long-run estimates in Panel A, it is ascertained that partial sum of negative change in consumer price index has negative and significant impact on Bitcoin prices, while partial sum of positive change in consumer price index has positive and insignificant impact on Bitcoin prices. Examined results of negative changes in consumer price index indicate that one unit decrease in consumer price index would leads to 57.089 units drop in Bitcoin prices.

Table 6. Asymmetric ARDL estimates

\begin{tabular}{|c|c|c|c|c|}
\hline \multicolumn{5}{|c|}{ Panel A: Long-run estimates } \\
\hline Variables & Coefficient & Std. Error & $\mathrm{t}$-Statistic & Prob. \\
\hline $\mathrm{CPI}^{+}$ & 6.18560 & 15.7223 & 0.39342 & 0.6953 \\
\hline $\mathrm{CPI}^{-}$ & $-57.0898 * * *$ & 30.9140 & -1.84673 & 0.0693 \\
\hline DJIA $^{+}$ & $4.31681 * * *$ & 2.48615 & 1.73634 & 0.0872 \\
\hline DJIA $^{-}$ & -1.36661 & 2.72235 & -0.50199 & 0.6174 \\
\hline FEDRATE $^{+}$ & 0.40670 & 0.37658 & 1.07998 & 0.2841 \\
\hline FEDRATE $^{-}$ & 0.41394 & 0.60304 & 0.68642 & 0.4949 \\
\hline $\mathrm{OIL}^{+}$ & 1.35276 & 1.90830 & 0.70888 & 0.4809 \\
\hline $\mathrm{OIL}^{-}$ & 3.32997 & 2.02002 & 1.64848 & 0.1041 \\
\hline USDI $^{+}$ & -3.74647 & 3.58367 & -1.04542 & 0.2997 \\
\hline $\mathrm{USDI}^{-}$ & -2.53412 & 6.94849 & -0.36470 & 0.7165 \\
\hline $\mathrm{GOLD}^{+}$ & -0.33255 & 3.09600 & -0.10741 & 0.9148 \\
\hline $\mathrm{GOLD}^{-}$ & 3.89278 & 2.78712 & 1.39670 & 0.1673 \\
\hline $\mathrm{GSCI}^{+}$ & -1.86562 & 3.64764 & -0.51145 & 0.6108 \\
\hline $\mathrm{GSCI}^{-}$ & -1.71132 & 3.08375 & -0.55494 & 0.5808 \\
\hline HASHRATE $^{+}$ & 0.09569 & 0.07779 & 1.23013 & 0.2231 \\
\hline HASHRATE $^{-}$ & $0.96791 * * *$ & 0.49724 & 1.94655 & 0.0559 \\
\hline VOLUME $^{+}$ & $0.33596^{*}$ & 0.08893 & 3.77747 & 0.0003 \\
\hline VOLUME $^{-}$ & 0.08367 & 0.12144 & 0.68896 & 0.4933 \\
\hline TRANS $^{+}$ & 0.32464 & 0.25228 & 1.28683 & 0.2027 \\
\hline TRANS $^{-}$ & $1.00403 * *$ & 0.43955 & 2.28424 & 0.0256 \\
\hline GOOGLE $^{+}$ & 0.01383 & 0.01474 & 0.93774 & 0.3518 \\
\hline GOOGLE $^{-}$ & 0.02300 & 0.01437 & 1.59971 & 0.1145 \\
\hline $\mathrm{C}$ & $-3.44020 *$ & 0.58436 & -5.88711 & 0.0000 \\
\hline
\end{tabular}


Review of Economic Analysis 14 (2022) 143-175

\begin{tabular}{|c|c|c|c|c|}
\hline \multicolumn{5}{|c|}{ Panel B: Short-run estimates } \\
\hline Variables & Coefficient & Std. Error & t-Statistic & Prob. \\
\hline$\Delta \mathrm{CPI}^{+}$ & -13.8734 & 9.54813 & -1.45299 & 0.1510 \\
\hline$\Delta \mathrm{CPI}^{-}$ & $-36.4648 * * *$ & 19.5572 & -1.86451 & 0.0668 \\
\hline$\Delta \mathrm{DJIA}^{+}$ & 0.55083 & 1.06369 & 0.51785 & 0.6063 \\
\hline$\Delta \mathrm{DJIA}^{-}$ & -0.05443 & 1.06417 & -0.05114 & 0.9594 \\
\hline$\triangle$ FEDRATE $^{+}$ & 0.16641 & 0.20701 & 0.80391 & 0.4244 \\
\hline$\Delta$ FEDRATE $^{-}$ & $-0.50800 * * *$ & 0.28022 & -1.81280 & 0.0745 \\
\hline$\Delta \mathrm{OIL}^{+}$ & 1.07862 & 0.72581 & 1.48609 & 0.1421 \\
\hline$\Delta \mathrm{OIL}^{-}$ & $1.62606 * *$ & 0.68411 & 2.37689 & 0.0204 \\
\hline$\Delta \mathrm{USDI}^{+}$ & -2.64831 & 1.68148 & -1.57498 & 0.1201 \\
\hline$\Delta \mathrm{USDI}^{-}$ & 3.02147 & 2.40923 & 1.25412 & 0.2143 \\
\hline$\Delta \mathrm{GOLD}^{+}$ & 0.54185 & 1.00704 & 0.53806 & 0.5924 \\
\hline$\Delta \mathrm{GOLD}^{-}$ & 1.30774 & 1.24498 & 1.05041 & 0.2974 \\
\hline$\Delta \mathrm{GSCI}^{+}$ & 0.11045 & 0.80329 & 0.13750 & 0.8911 \\
\hline$\Delta \mathrm{GSCI}^{-}$ & $-1.30794 * * *$ & 0.78360 & -1.66913 & 0.0999 \\
\hline$\Delta$ HASHRATE $^{+}$ & $0.29726^{*}$ & 0.06570 & 4.52464 & 0.0000 \\
\hline$\Delta$ HASHRATE $^{-}$ & $1.41044 *$ & 0.32584 & 4.32852 & 0.0001 \\
\hline$\Delta$ VOLUME $^{+}$ & $0.21292 *$ & 0.03201 & 6.65139 & 0.0000 \\
\hline$\Delta$ VOLUME $^{-}$ & $-0.08855 * * *$ & 0.04619 & -1.91703 & 0.0596 \\
\hline$\Delta$ TRANS $^{+}$ & $0.66481 *$ & 0.12062 & 5.51131 & 0.0000 \\
\hline$\Delta$ TRANS $^{-}$ & -0.00285 & 0.20109 & -0.01419 & 0.9887 \\
\hline$\Delta$ GOOGLE $^{+}$ & $-0.00675 * * *$ & 0.00352 & -1.91481 & 0.0599 \\
\hline$\Delta$ GOOGLE $^{-}$ & $0.02995 *$ & 0.00472 & 6.34200 & 0.0000 \\
\hline $\mathrm{D} 1$ & $0.56169 *$ & 0.07140 & 7.86623 & 0.0000 \\
\hline $\mathrm{D} 2$ & $0.35604 *$ & 0.05493 & 6.48097 & 0.0000 \\
\hline $\mathrm{ECT}_{\mathrm{t}-1}$ & $-0.67597 *$ & 0.06401 & -10.5602 & 0.0000 \\
\hline
\end{tabular}

Note: $* * *$ and $* * *$ denotes significance at $1 \%, 5 \%$ and $10 \%$ level, respectively.

The partial sum of positive change in US stock market index has positive and significant impact on Bitcoin prices, while partial sum of negative change in US stock market index has negative and insignificant impact on Bitcoin prices. This implies that one unit rise in US stock market index would raise Bitcoin prices by 4.316 units. Besides, the table results reveal that negative or positive shocks of other macroeconomic and financial factors do not have significant effect on Bitcoin price in the long-run. With respect to the internal factors, the partial sum of negative changes in hash rate and network activity has positive and significant impact on Bitcoin prices, respectively. 
Results of asymmetric short-run estimates in Panel B indicates that the negative shocks in consumer price index has negative and significant impact on Bitcoin prices. This shows that one percent decrease in consumer price index would leads to 57.089 percent drop in Bitcoin prices. It is found that a negative shock in Federal Funds rate with a statistically significant negative coefficient, implies that the one percent decrease in Federal Funds rate causes digital coin price to drop by 0.508 percent. In the short-run, it is found that a negative shock in oil price with a statistically significant positive coefficient, implying that the one percent drop in oil price causes Bitcoin price to rise by 1.626 percent. Examined results of negative changes in GSCI commodity market index indicate that one unit decrease in commodity market index would leads to drop in the Bitcoin prices by 1.307 percent in the short-run. Moreover, the results reveal that internal factors such as trading volume, network activity, hash rate and Google trends had significant asymmetric responses to the changes in Bitcoin prices. The coefficient of the error correction term value (-0.675) suggests that about 67 percent of disequilibrium in the Bitcoin prices is corrected in the current year.

To check the robustness of the estimated symmetric and asymmetric ARDL approaches, the diagnostic tests were employed and the results are shown in Table 7. From Panel A and Panel $\mathrm{B}$, it is inferred that symmetric and asymmetric estimations passes all diagnostic tests. Besides, the plot of both CUSUM and CUSUMQ statistics for symmetric and asymmetric ARDL approaches lie between the critical bounds at 5 percent significance level (Refer Figure 8 and Figure 9). This confirms that estimated coefficients from the symmetric and asymmetric models were parametrically stable over the sample period.

Table 7. Diagnostic checks

\begin{tabular}{|l||c|c|}
\hline \multicolumn{3}{|c|}{ Panel A: Symmetric ARDL Model } \\
\hline $\begin{array}{l}\text { Breusch-Godfrey Serial Correlation LM } \\
\text { test }\end{array}$ & test statistic & Prob. value \\
\hline Jarque-Bera Normality test & 0.94198 & 0.3345 \\
\hline ARCH-LM Heteroscedasticity test & 1.03920 & 0.2474 \\
\hline Ramsey RESET Specification test & 0.01564 & 0.3007 \\
\hline \multicolumn{2}{|c|}{ Panel B: Asymmetric ARDL Model } \\
\hline \multicolumn{2}{|c|}{0.97961} & 0.3250 \\
\hline \hline $\begin{array}{l}\text { Breusch-Godfrey Serial Correlation LM } \\
\text { test }\end{array}$ & 1.23825 & 0.2700 \\
\hline Jarque-Bera Normality test & 1.48739 & 0.2084 \\
\hline ARCH-LM Heteroscedasticity test & 0.12397 & 0.7254 \\
\hline Ramsey RESET Specification test & 0.02694 & 0.8701 \\
\hline
\end{tabular}


Review of Economic Analysis 14 (2022) 143-175

Figure 8. Parameters stability test for Symmetric ARDL model
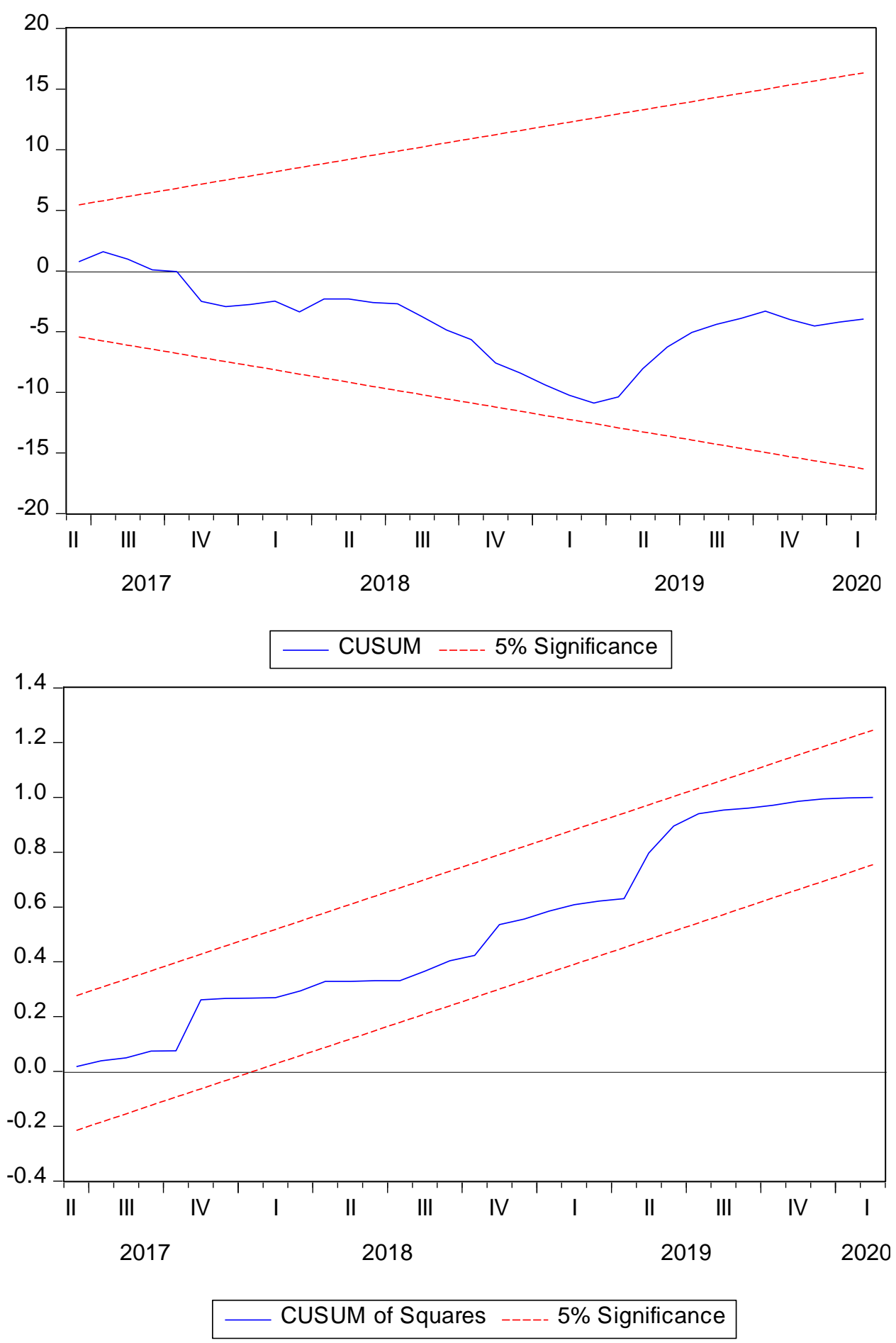
SRINIVASAN, MAITY, KUMAR Macro-Financial Parameters and Bitcoin Prices

Figure 9. Parameters stability test for asymmetric ARDL model
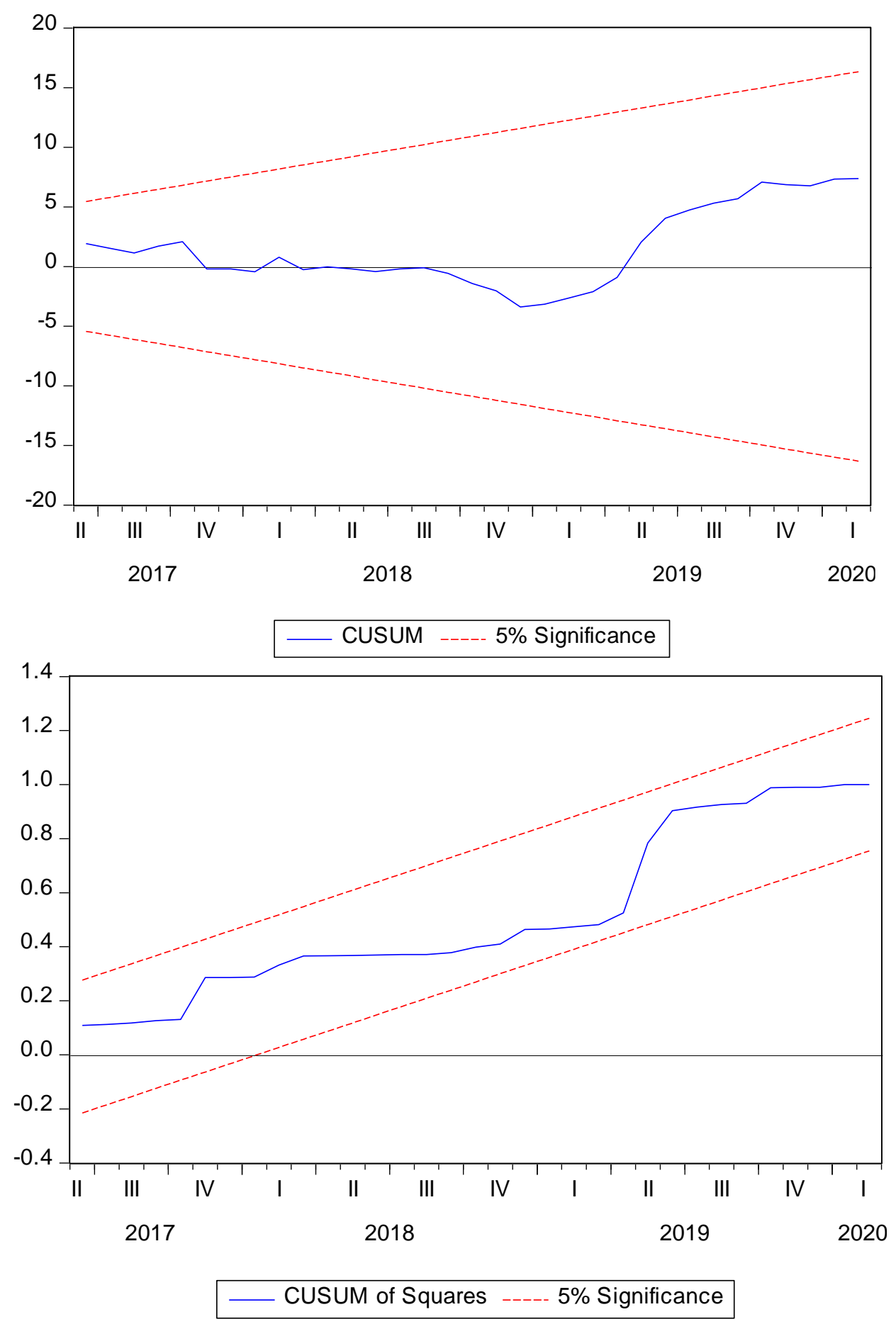


\section{Conclusion}

The present study examines the impact of macroeconomic-financial indicators on Bitcoin price using symmetric and asymmetric version of autoregressive distributed lag model (ARDL) models with structural breaks. Based on the availability of monthly time series data, the study covers the period from August 2010 to February 2020. The symmetric and asymmetric ARDL bound tests indicates that there exists a long run association between Bitcoin prices and macroeconomic-financial indicators. Moreover, the dynamic multiplier analysis confirms the asymmetric co-integration effects of positive and negative changes in macroeconomic and financial indicators on Bitcoin prices in both the short run and the long run. We applied both symmetric and asymmetric ARDL approaches, but ascertained mixed evidence with respect to short-run and long-run estimates. Following, Ajaz et al. (2016) and Kocaarslan and Soytas (2019), it is considered that the results of asymmetric ARDL approaches because ignoring asymmetric response in modeling the relationship will result in misleading inference or spurious conclusions.

There is enough evidence based on the asymmetric ARDL model that suggests the negative changes in Consumer Price Index (decrease in Consumer Price Index) has negative and significant impact on Bitcoin prices in the short-run and long-run, implying that Bitcoin cannot be used to hedge against the inflation. The positive shocks in Dow Jones Index (rise in stock market index) exerts a positive and significant long term influence on Bitcoin prices, while the impact is insignificant in the short-run. This implies that Bitcoin cannot be regarded as a hedging device for the stock market. Besides, the negative stocks in Federal Funds rate and GSCI commodity market index had significant negative impact on Bitcoin price in the shortrun, implying that Bitcoin cannot be used to hedge against these asset classes. Moreover, these assets are found to have insignificant impact in the long-run. The Crude oil price had significant negative impact on Bitcoin price in the short-run, implying that Bitcoin can be used to hedge against the oil prices. Besides, the results reveal that internal factors such as hash rate, trading volume and network activity had significant asymmetric responses to the changes in Bitcoin prices in the long-run and short-run. The Google trends (investor sentiment) had significant impact in the short-run, whereas its impact is insignificant in the long-run. The findings from the present study have significant implications for market participants, who consider including alternate investment assets in their portfolios. 
SRINIVASAN, MAITY, KUMAR Macro-Financial Parameters and Bitcoin Prices

\section{References}

Adebola, S. S, Gil-Alana, L. A, and Madigu, G. (2019). Gold prices and the cryptocurrencies: Evidence of convergence and cointegration. Physica A: Statistical Mechanics and its Applications, 523, 1227-1236.

Ajaz, T, Naina, M.Z, and Kamaiah, B. (2016), Inflation and openness in India: An asymmetric approach. Macroeconomics and Finance in Emerging Market Economies, 9(2), 190-203.

Andrean, G. (2019). Determinant of the Bitcoin Prices as Alternative Investment in Indonesia. Indicators-Journal of Economic and Business, 1(1), 22-29.

Bai, J, and Perron, P. (1998). Estimating and Testing Linear Models with Multiple Structural Changes. Econometrica 1, 47-78.

Bai, J, and Perron, P. (2003). Computation and Analysis of Multiple Structural Change Models. Journal of Applied Econometrics 18(1), 1-22.

Balcilar, M, Bouri, E, Gupta, R, and Roubaud, D. (2017). Can volume predict Bitcoin returns and volatility? A quantiles-based approach. Economic Modelling, 64, 74-81.

Barro, R. J. (1974). Are government bonds net wealth? Journal of Political Economy 82(6), 1095-1117.

Bayramoğlu, A. T, and Başarır, Ç. (2019). The Linkage Between Cryptocurrencies and MacroFinancial Parameters: A Data Mining Approach. In Blockchain Economics and Financial Market Innovation (pp. 249-269). Springer, Cham.

Bouoiyour, J, and Selmi, R. (2015). What does Bitcoin look like?. Annals of Economics and Finance, 16(2), 449-492.

Bouri, E, Azzi, G, and Haubo Dyhrberg, A, (2017). On the return-volatility relationship in the Bitcoin market around the price crash of 2013. Economics: The Open-Access. Open-Assess. E-J. 11, 1-17

Bouri, E, Gupta, R, Lahiani, A, and Shahbaz, M. (2018). Testing for asymmetric nonlinear short-and long-run relationships between bitcoin, aggregate commodity and gold prices. Resources Policy, 57, 224-235.

Brown, R. L, Durbin, J. and Evans, J. M. (1975). Techniques for Testing the Constancy of Regression Relations over Time. Journal of the Royal Statistical Society, Series B, 37, 149163.

Buchholz, M, Delaney, J, Warren, J, and Parker, J. (2012). Bits and bets, information, price volatility, and demand for Bitcoin. Economics, 312, 2-48.

Canh, N. P, Binh, N. Q, and Thanh, S. D. (2019). Cryptocurrencies and Investment Diversification: Empirical Evidence from Seven Largest Cryptocurrencies. Theoretical Economics Letters, 9(3), 431-452 
Charfeddine, L, Benlagha, N, and Maouchi, Y. (2020). Investigating the dynamic relationship between cryptocurrencies and conventional assets: Implications for financial investors. Economic Modelling, 85, 198-217.

Ciaian, P, and Rajcaniova, M. d'Artis Kancs, (2018). Virtual relationships: Short-and longrun evidence from Bitcoin and altcoin markets. Journal of International Financial Markets, Institutions and Money, 52, 173-195.

Ciaian, P, and Rajcaniova, M, and Kancs, D. A. (2016a). The economics of BitCoin price formation. Applied Economics, 48(19), 1799-1815.

Ciaian, P, and Rajcaniova, M, and Kancs, D. A. (2016b). The digital agenda of virtual currencies: Can BitCoin become a global currency?. Information Systems and e-Business Management, 14(4), 883-919.

Corbet, S, Larkin, C, Lucey, B, Meegan, A, Yarovaya, L. (2020). The impact of macroeconomic news on Bitcoin returns, The European Journal of Finance, 26(14), 1396-1416.

Das, D, and Kannadhasan, M. (2018). Do global factors impact bitcoin prices? Evidence from Wavelet approach. Journal of Economic Research, 23, 227-264.

Dube, A. K, Ozkan, B. and Govindasamy, R. (2018). Analyzing the Export Performance of the Horticultural Sub-Sector in Ethiopia: ARDL Bound Test Cointegration Analysis. Horticulturae. 34(4), 1-18.

Dyhrberg, A. H. (2016). Bitcoin, gold and the dollar-A GARCH volatility analysis. Finance Research. Letters. 16, 85-92.

Gandal, N, Hamrick, J. T, Moore, T, and Oberman, T. (2018). Price manipulation in the Bitcoin ecosystem. Journal of Monetary Economics, 95, 86-96.

Glaser, F, Haferhorn, M, Weber, M.C, Zimmermann, K. and Siering, M. (2014). BitcoinAsset or Currency? Revealing Users' Hidden Intentions. Paper presented at Twenty Second European Conference on Information Systems, Tel Aviv, Israel, June 9-14, 1-14.

Goczek, Ł, and Skliarov, I. (2019). What drives the Bitcoin price? A factor augmented error correction mechanism investigation. Applied Economics, 51(59), 6393-6410.

Gregory, A and Hansen, B. (1996).Residual-based Tests for Cointegration in Models with Regime Shifts. Journal of Econometrics, 70, 99-126.

Gurrib, I, Kweh, Q. L, Nourani, M, and Ting, I. W. K. (2019). Are cryptocurrencies affected by their asset class movements or news announcements? Malaysian Journal of Economic Studies, 56(2), 201-225.

İçellioğlu, C. S. and Öner, S. (2019). An Investigation on the Volatility of Cryptocurrencies by means of Heterogeneous Panel Data Analysis. Procedia Computer Science. 158, 913-920.

Ji, Q, Bouri, E, Gupta, R, and Roubaud, D. (2018). Network causality structures among Bitcoin and other financial assets: A directed acyclic graph approach. The Quarterly Review of Economics and Finance, 70, 203-213. 


\section{SRINIVASAN, MAITY, KUMAR Macro-Financial Parameters and Bitcoin Prices}

Keynes, J. M. (1936). The General Theory of Employment, Interest, and Money. New York: Harcourt-Brace and World, Inc.

Kisswani, K. M. (2017). Evaluating the GDP-energy consumption nexus for the ASEAN-5 countries using nonlinear ARDL model. OPEC Energy Review, 41(4), 318-343

Kjærland, F, Khazal, A, Krogstad, E. A, Nordstrøm, F. B, and Oust, A. (2018). An analysis of bitcoin's price dynamics. Journal of Risk and Financial Management, 11(4), 1-18.

Kocaarslan, B. and Soytas, U. (2019). Asymmetric pass-through between oil prices and the stock prices of clean energy firms: New evidence from a nonlinear analysis. Energy Reports, $5,117-125$.

Kristoufek, L. (2013). BitCoin meets Google Trends and Wikipedia: Quantifying the relationship between phenomena of the Internet era. Scientific reports, 3, 1-7

Kurka, J. (2019). Do cryptocurrencies and traditional asset classes influence each other? Finance Research Letters, 31, 38-46.

Kusumastuty, C. A, Wulandari, D, Narmaditya, B. S, and Kamaludin, M. (2019). Do Monetary Variables Affect to Cryptocurrency Price? Lesson from Indonesia. Jurnal Ekonomi dan Studi Pembangunan, 11(2), 131-142.

Leybourne, S. and Newbold, P. (2003). Spurious rejections by cointegration tests induced by structural breaks. Applied Economics, 35(9), 1117-1121

Nai-Fovino, I, Steri, G, Fontana, A, Ciaian, P, Kancs, D, and Nordvik, J.P. (2015). On Virtual and Crypto Currencies: A General Overview, from the technological aspects to the economic implications. JRC Technical Report JRC99978.

Nguyen, T. V. H, Nguyen, B. T, Nguyen, K. S, and Pham, H. (2019). Asymmetric monetary policy effects on cryptocurrency markets. Research in International Business and Finance, 48, 335-339.

Panagiotidis, T, Stengos, T, and Vravosinos, O. (2019). The effects of markets, uncertainty and search intensity on bitcoin returns. International Review of Financial Analysis, 63, 220-242.

Perron, P. (1989). The Great Crash, the Oil Price Shock, and the Unit Root Hypothesis. Econometrica 57(6), 1361-1401.

Pesaran M. H, and Pesaran, B. (1997). Working with Microfit 4.0: Interactive Econometric Analysis. Oxford, Oxford University Press.

Pesaran, M. H, Shin, Y. and Smith, R. (1996). Testing for the existence of a long-run relationship. DAE Working Paper 9622, Department of Applied Economics, University of Cambridge.

Pesaran, M. H, Shin, Y. and Smith, R. (2001). 'Bounds testing approaches to the analysis of level relationships. Journal of Applied Econometrics, 16, 289-326.

Popper, N. (2015). Can Bitcoin Conquer Argentina? The New York Times, April 29.

Poyser, O. (2017). Exploring the determinants of Bitcoin's price: an application of Bayesian Structural Time Series. arXiv preprint arXiv:1706.01437. 
Poyser, O. (2019). Exploring the dynamics of Bitcoin's price: a Bayesian structural time series approach. Eurasian Economic Review, 9(1), 29-60.

Pyo, S, and Lee, J. (2019). Do FOMC and macroeconomic announcements affect Bitcoin prices? Finance Research Letters, 101386. doi: https://doi.org/10.1016/j.frl.2019.101386

Samah, H, Wajdi, M, and Regaieg, R. (2018). Dynamic Linkages among Bitcoin, gold prices and Exchange rates of US Dollar in JPY, GBP and CNY: DCC EGARCH Approach. Journal of Academic Research in Economics, 10(2), 239-247.

Shin, Y, Yu, B, Greenwood-Nimmo, M. (2014). Modelling asymmetric cointegration and dynamic multipliers in an ARDL framework. In: Horrace, W.C, Sickles, R.C. (Eds.), Festschrift in Honor of Peter Schmidt. Springer Science and Business Media, New York (NY).

Sukamulja, S, and Sikora, C. O. (2018). The new era of financial innovation: the determinants of bitcoin's price. Journal of Indonesian Economy and Business, 33(1), 46-64.

Tiwari, A. K, Raheem, I. D, and Kang, S. H. (2019). Time-varying dynamic conditional correlation between stock and cryptocurrency markets using the copula-ADCC-EGARCH model. Physica A: Statistical Mechanics and its Applications, 535, 1-9.

Ünvana, Y. A. (2019). Impacts of Bitcoin on USA, Japan, China and Turkey stock market indexes: Causality analysis with value at risk method (VAR). Communications in StatisticsTheory and Methods, https://doi.org/10.1080/03610926.2019.1678644

Vaddepalli, S, and Antoney, L. (2018). Are economic factors driving Bitcoin transactions? an analysis of select economies. Finance Research Letters, 163(12), 106-109.

Vogelsang, T. J. (1993). Essays on testing for non-stationarities and structural change in time series models. Unpublished Ph.D. Dissertation. Department of Economics, Princeton University, Princeton, NJ.

Wijk, V. D. (2013). What can be expected from the BitCoin. Erasmus Universiteit Rotterdam.

Zhu, Y, Dickinson, D, and Li, J. (2017). Analysis on the influence factors of Bitcoin's price based on VEC model. Financial Innovation, 3(1), 1-13.

Zwick, H. S, and Syed, S. A. S. (2019). Bitcoin and Gold Prices: A Fledging Long-Term Relationship. Theoretical Economics Letters, 9(7), 2516-2525. 
SRINIVASAN, MAITY, KUMAR Macro-Financial Parameters and Bitcoin Prices

\section{Appendix 1.}

Asymmetric Cumulative Dynamic Muliplier
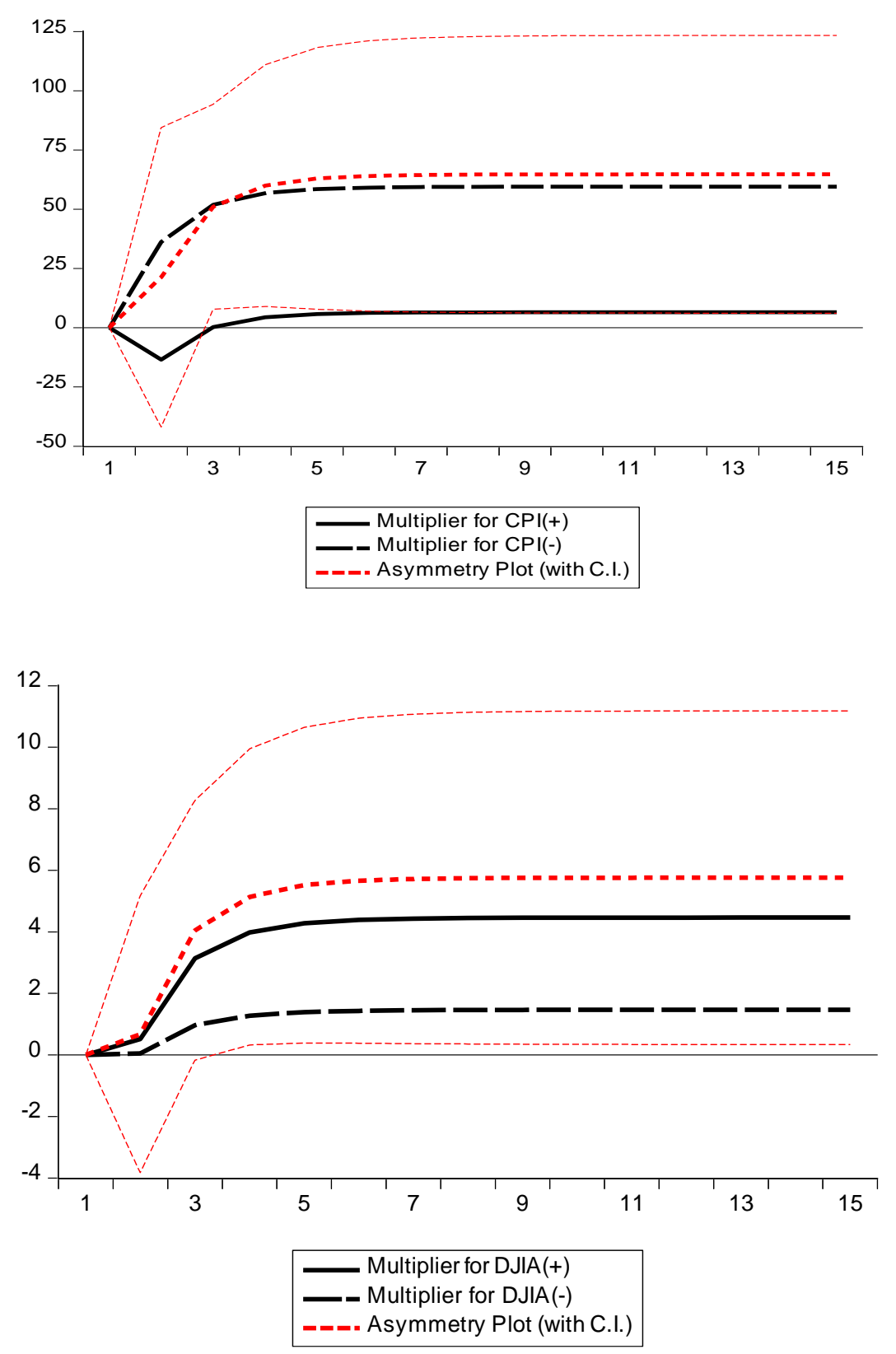
Review of Economic Analysis 14 (2022) 143-175
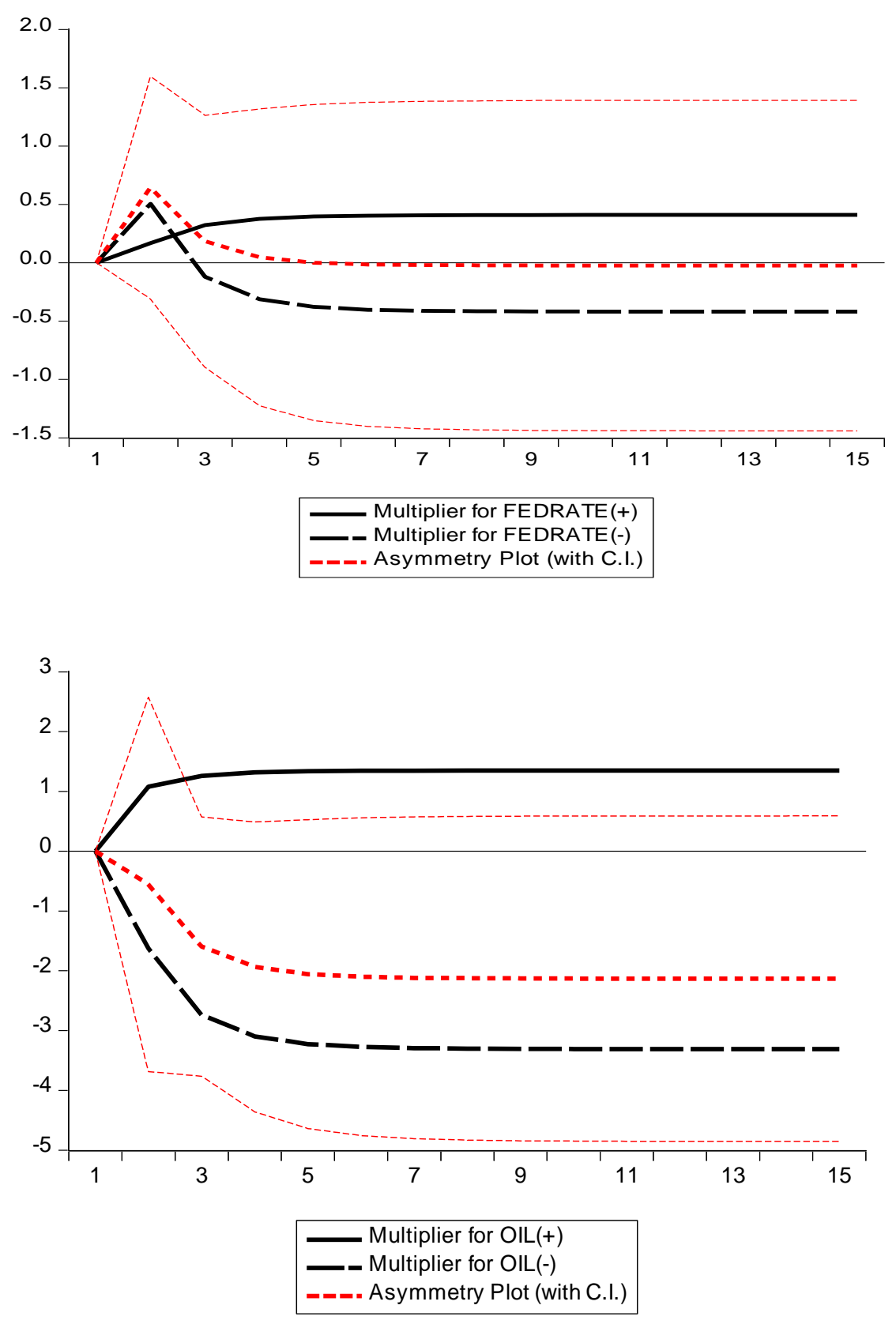
SRINIVASAN, MAITY, KUMAR Macro-Financial Parameters and Bitcoin Prices
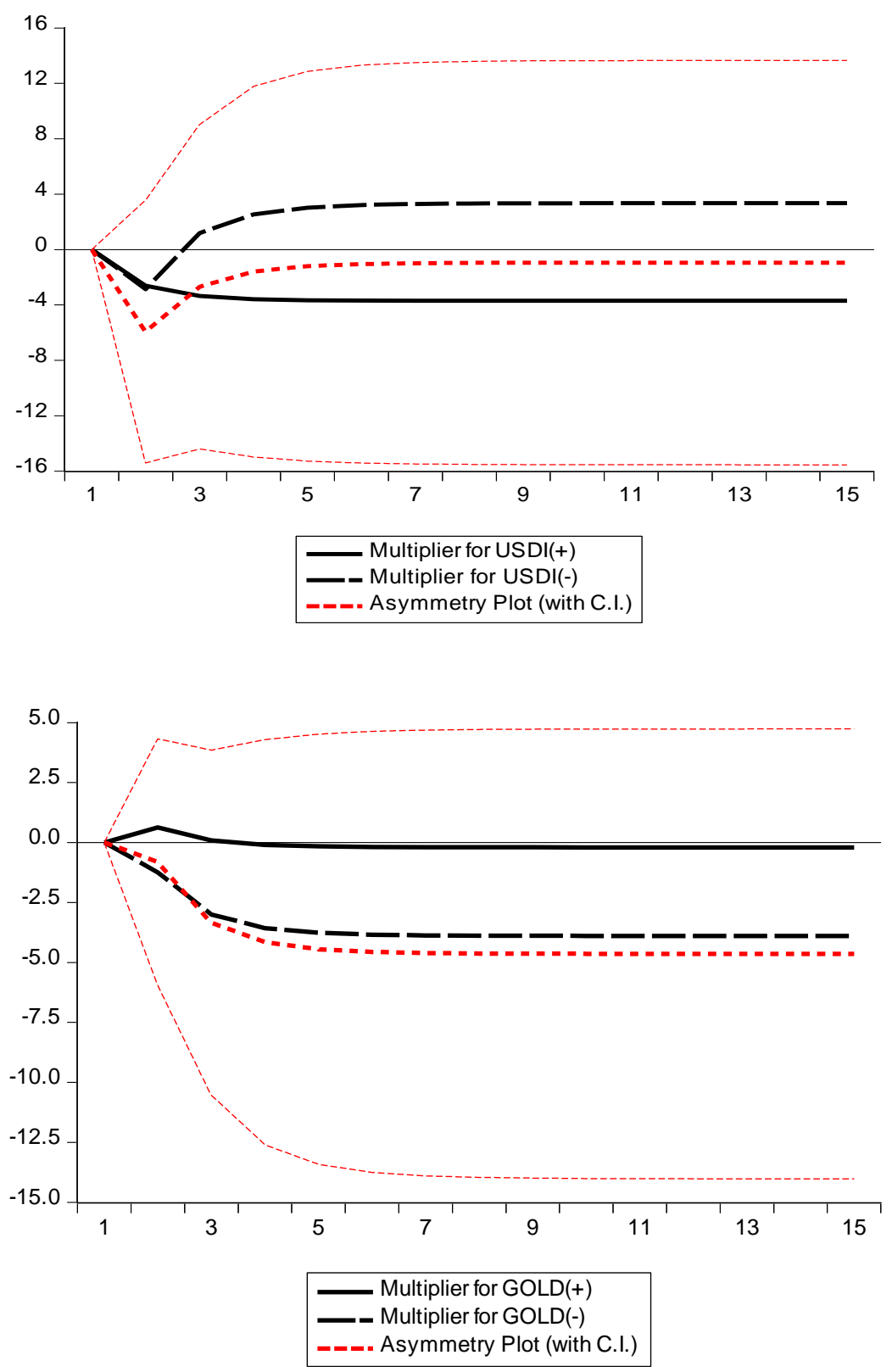
Review of Economic Analysis 14 (2022) 143-175
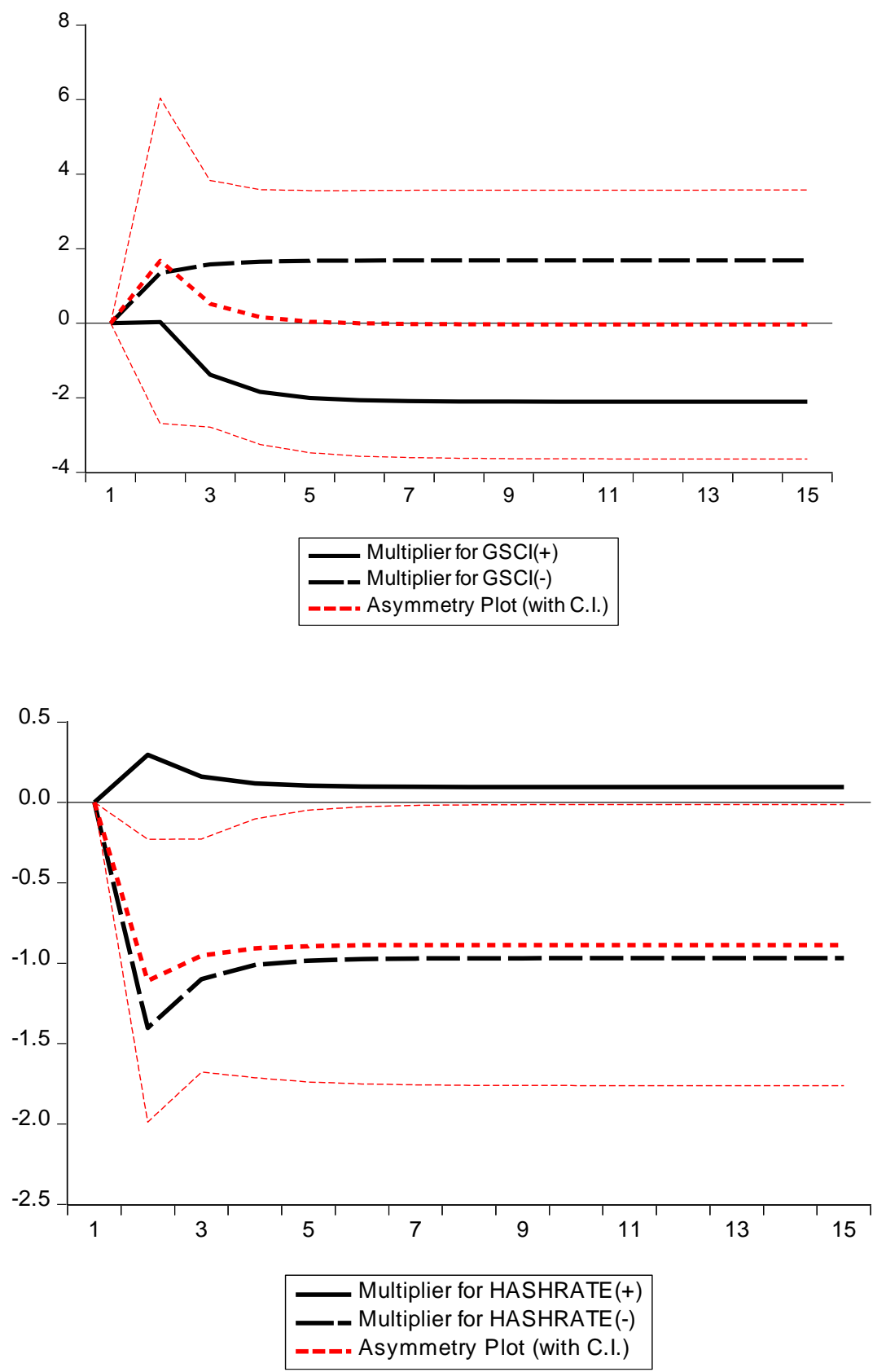
SRINIVASAN, MAITY, KUMAR Macro-Financial Parameters and Bitcoin Prices
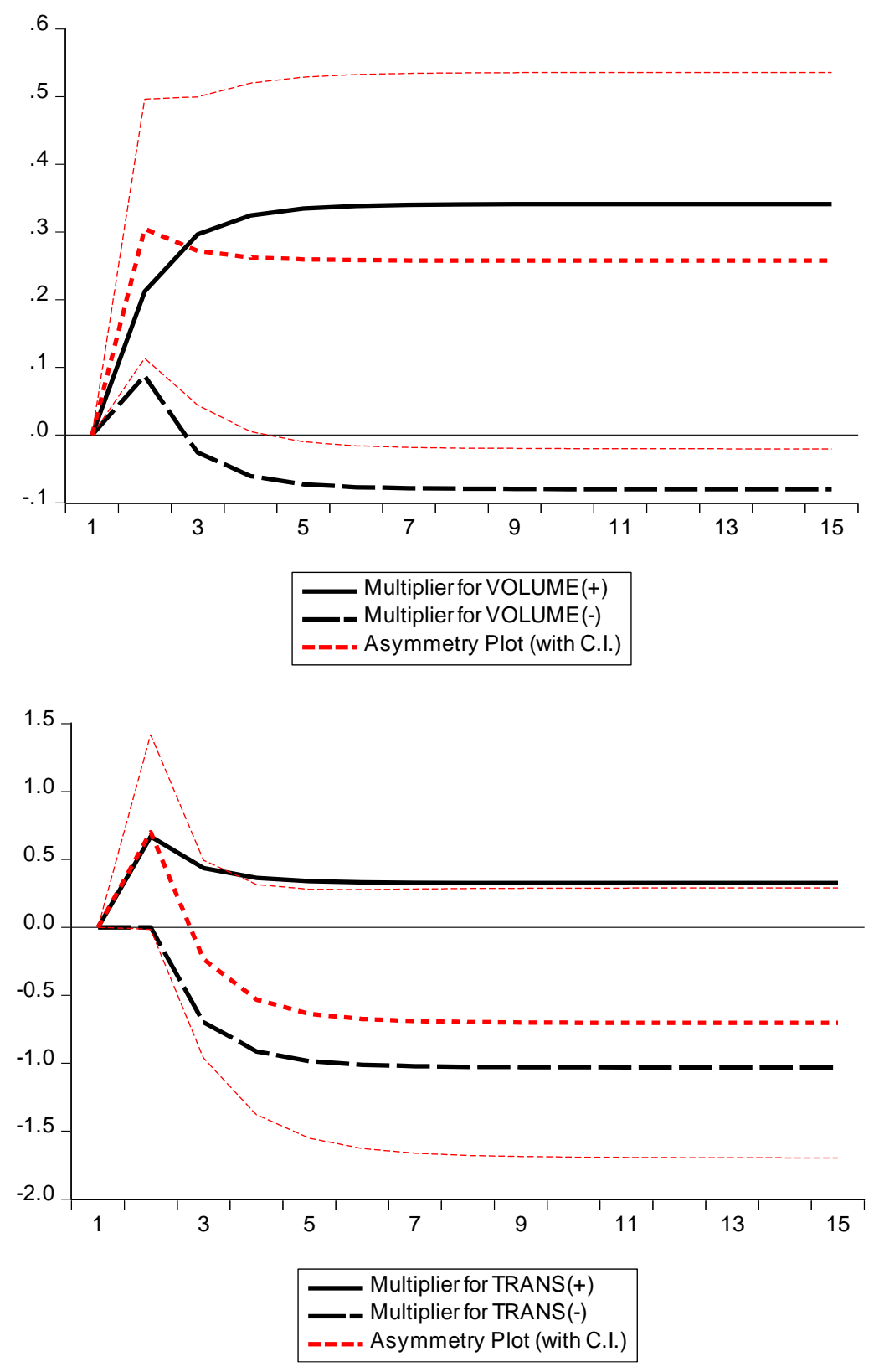